Chapman University

Chapman University Digital Commons

Pharmaceutical Sciences (MS) Theses

Dissertations and Theses

Summer 8-2021

\title{
Cost-Effectiveness Analysis of Tisagenlecleucel, Blinatumomab, and Clofarabine for Treatment of B-cell Precursor Acute Lymphoblastic Leukemia
}

\author{
Kamron Lotfi \\ Chapman University, klotfi@chapman.edu
}

Follow this and additional works at: https://digitalcommons.chapman.edu/

pharmaceutical_sciences_theses

Part of the Health Services Research Commons, Other Pharmacy and Pharmaceutical Sciences

Commons, Patient Safety Commons, Pharmacoeconomics and Pharmaceutical Economics Commons, and the Pharmacy Administration, Policy and Regulation Commons

\section{Recommended Citation}

Lotfi, K. Cost-Effectiveness Analysis of Tisagenlecleucel, Blinatumomab, and Clofarabine for Treatment of B-cell Precursor Acute Lymphoblastic Leukemia. [master's thesis]. Irvine, CA: Chapman University; 2021.

https://doi.org/ 10.36837/chapman.000294

This Thesis is brought to you for free and open access by the Dissertations and Theses at Chapman University Digital Commons. It has been accepted for inclusion in Pharmaceutical Sciences (MS) Theses by an authorized administrator of Chapman University Digital Commons. For more information, please contact laughtin@chapman.edu. 


\title{
Cost-Effectiveness Analysis of Tisagenlecleucel, Blinatumomab, and
}

\section{Clofarabine for Treatment of B-cell Precursor Acute Lymphoblastic}

\author{
Leukemia
}

\author{
A Thesis by \\ Kamron Lotfi
}

\author{
Chapman University \\ Irvine, $\mathrm{CA}$ \\ School of Pharmacy \\ Harry and Diane Rinker Health Science \\ Submitted in partial fulfillment of the requirements for the degree of \\ Master of Science in Pharmaceutical Science
}

August 2021

Committee in charge:

Enrique Seoane-Vazquez, Ph.D.; Chair

Rosa Rodriguez-Monguio, M.S, Ph.D.

Lawrence M. Brown, Pharm.D., Ph.D.; FAPhA 
The thesis of Kamron Lotfi is approved.

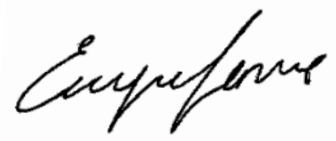

Enrique Seoane-Vazquez, Ph.D.; Chair

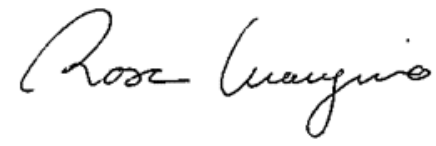

Rosa Rodriguez-Monguio, M.S, Ph.D.

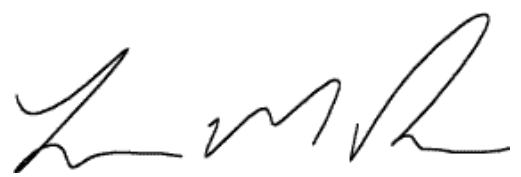

Lawrence M. Brown, Pharm.D., Ph.D.; FAPhA

June 2021 
Cost-Effectiveness Analysis of Tisagenlecleucel, Blinatumomab, and Clofarabine for Treatment of B-cell Precursor Acute Lymphoblastic

Copyright (C) 2021

by Kamron Lotfi 


\begin{abstract}
Cost-Effectiveness Analysis of Tisagenlecleucel, Blinatumomab, and Clofarabine for Treatment of B-cell Precursor Acute Lymphoblastic Leukemia

by Kamron Lotfi

\section{Introduction}

Acute lymphoblastic leukemia (ALL) is a common type of adolescent and young adult leukemia in the United States (U.S.). Patients who are refractory or relapsed after receiving two or more lines of systemic therapy have the option of taking tisagenlecleucel. Due to the high cost of this treatment, a cost-effectiveness analysis was performed to assess the treatments for tisagenlecleucel, clofarabine combination, and blinatumomab.
\end{abstract}

\title{
Objectives
}

The objective of this study is to evaluate the cost-effectiveness of tisagenlecleucel; clofarabine, etoposide, cyclophosphamide; and blinatumomab for the treatment of relapserefractory ALL for adolescents and young adults from the U.S. health care payer perspective.

\section{Material and Methods}

Clinical data were collected from the FDA databases, RedBook online, National Institutes of Health (NIH) research database, PubMed database, and clinicaltrials.gov. The cost information was extracted from the Redbook and published studies. The cost-effective analysis was performed using TreeAge Pro (Healthcare Version) version 2021.

\section{Results}

The incremental cost of tisagenlecleucel was $\$ 520,050$ compared to blinatumomab. The base case showed tisagenlecleucel effectiveness was the highest at 19.284, and blinatumomab effectiveness was 12.580 . Tisagenlecleucel had an ICER of $\$ 77,573$. The probability sensitivity 
analysis showed that tisagenlecleucel was $63.1 \%$ of the time, and clofarabine combination was dominated by tisagenlecleucel and blinatumomab.

\section{Conclusions}

Tisagenlecleucel and blinatumomab dominated the clofarabine combination. According to the results of the sensitivity analysis, tisagenlecleucel was more cost-effective $63.1 \%$ of the time. Blinatumomab was more cost-effective at a lower WTP and $35.8 \%$ of the time. 


\section{TABLE OF CONTENTS}

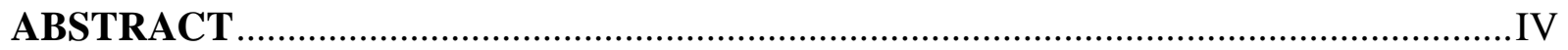

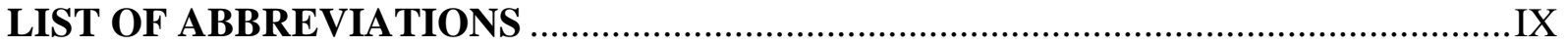

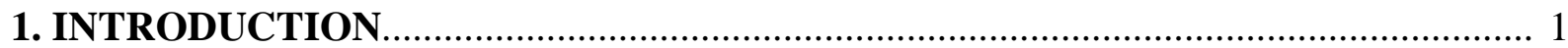

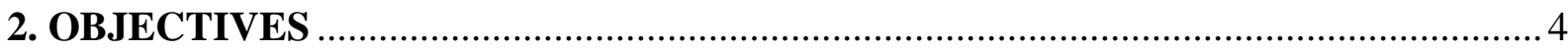

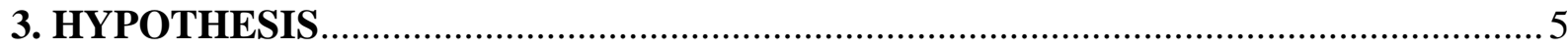

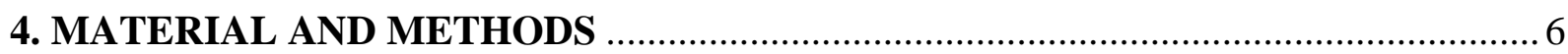

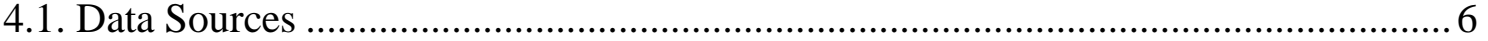

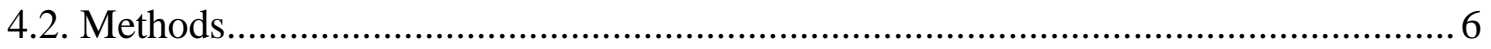

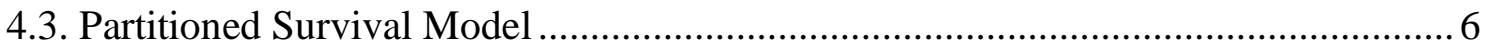

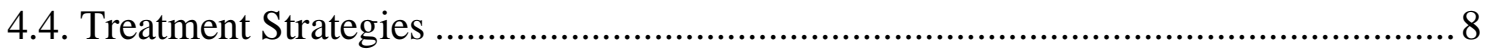

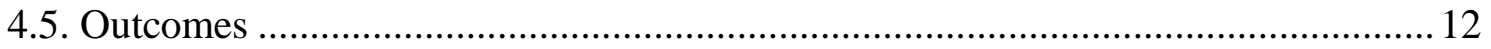

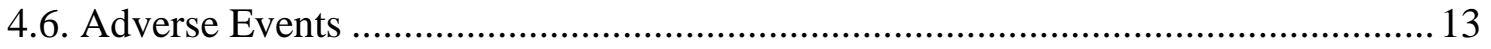

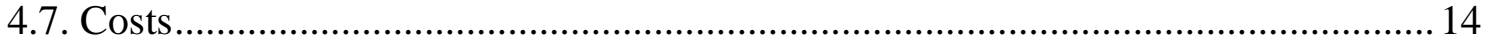

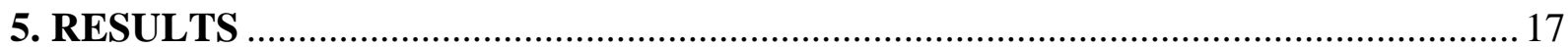

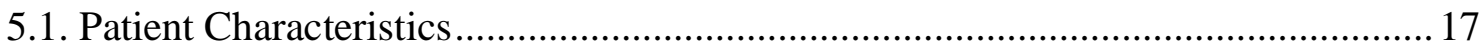

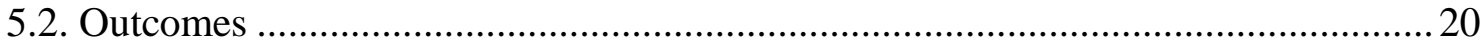

5.3. Cost-Effectiveness and Incremetnal Cost-Effectiveness .......................................2 23

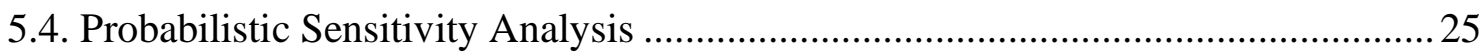

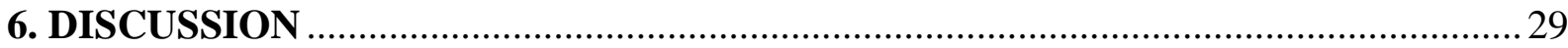

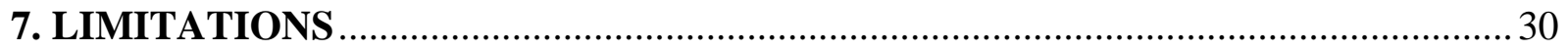

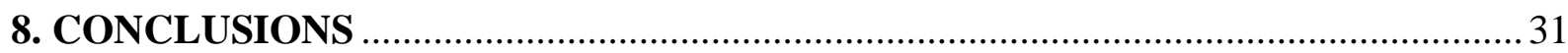

REFERENCES 


\section{LIST OF TABLES}

Table 1. Tisagenlecleucel, blinatumomab, and clofarabine FDA-Approved Indications.......... 9

Table 2. Treatment dosages for tisagenlecleucel, blinatumomab, and clofarabine ................. 10

Table 3. Treatment timeline of tisagenlecleucel .............................................................. 10

Table 4. Treatment timeline for blinatumomab ................................................................ 11

Table 5. Treatment timeline for clofarabine combination ................................................. 11

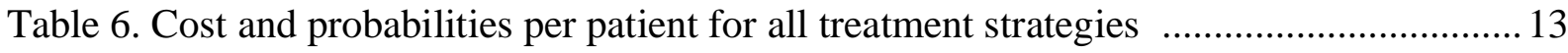

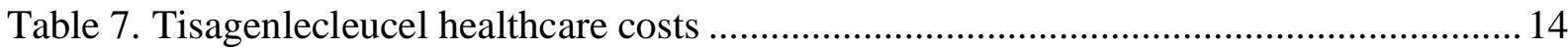

Table 8. Clofarabine combination healthcare costs ....................................................... 14

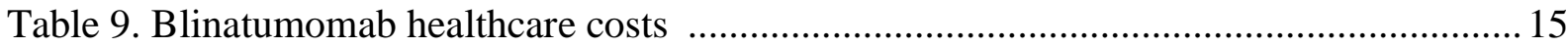

Table 10. Cost of palliative chemotherapy for relapsed/refractory patients ......................... 15

Table 11. Cost of individual grade 3-4 adverse events for each treatment strategy ............... 15

Table 12. Patient population of tisagenlecleucel clinical trial data (ELIANA) ..................... 17

Table 13. Patient population of blinatumomab clinical trials ............................................. 18

Table 14. Patient population of clofarabine with etoposide and cyclophosphamide

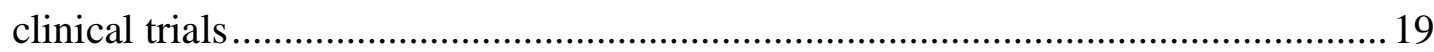

Table 15. Incremental cost, incremental effectiveness, ICER for tisagenlecleucel,

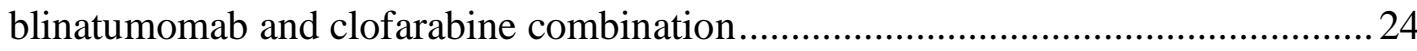




\section{LIST OF FIGURES}

Figure 1. States of the partitioned survival model ............................................................ 7

Figure 2. Tisagenlecleucel overall patient survival ..................................................................... 20

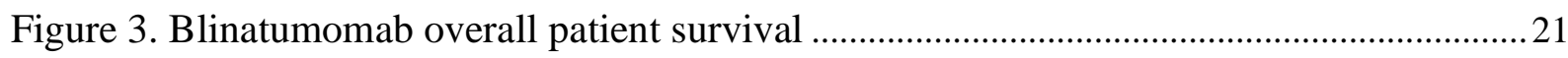

Figure 4. Clofarabine overall patient survival.................................................................. 21

Figure 5. Partitioned survival model curve of tisagenlecleucel....................................... 22

Figure 6. Partitioned survival model curve of blinatumomab. ........................................... 22

Figure 7. Partitioned survival model curve of clofarabine combination. ..............................23

Figure 8. Cost-effectiveness analysis results for all treatments.................................... 24

Figure 9. One-way cost-effectiveness sensitivity analysis of tisagenlecleucel.......................26

Figure 10. One-way cost-effectiveness sensitivity analysis of blinatumomab ..................... 26

Figure 11. Monte Carlo acceptability at WTP of 100,000 for all treatment alternatives.......... 27

Figure 12. Cost-effectiveness acceptability curve of tisagenlecleucel, blinatumomab,

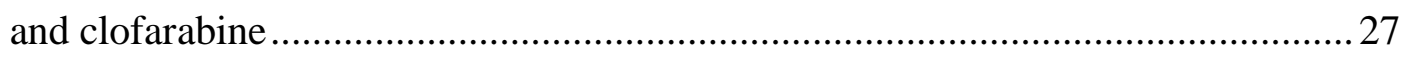

Figure 13. Monte Carlo probability distribution INMB of tisagenlecleucel vs.

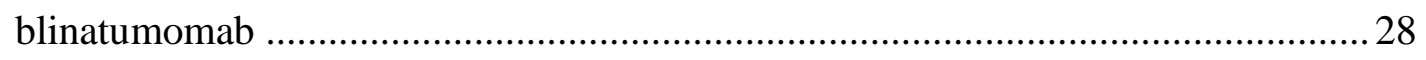




\section{LIST OF ABBREVIATIONS}

ALL Acute lymphoblastic leukemia

ALT Alanine aminotransferase

AST Aspartate aminotransferase

AWP Average wholesale price

CAR Chimeric antigen receptor

CER Comparative effectiveness research

CMS Centers for Medicare \& Medicaid Services

CPI Consumer price index

DLBCL Diffuse large B cell lymphoma

HSCT Hematopoietic stem cell transplant

IC Incremental cost

ICER Incremental cost-effectiveness ratio

INMB Incremental net monetary benefit

IVIG Intravenous immunoglobulin

LYS Life years saved

NHL Non-Hodgkin lymphoma

NIH National Institutes of Health

PSA Probabilistic sensitivity analysis

QALY Quality-adjusted life years

RR ALL Relapsed-refractory acute lymphoblastic leukemia

RR DLBCL Relapsed-refractory diffuse large B cell lymphoma

WAC Weighted average cost

WTP Willingness to pay 


\section{INTRODUCTION}

In the past decade, breakthroughs in cancer drug research of the human immune system resulted in the development of a new category of cancer drugs called immunotherapy. There are different types of immunotherapy cancer treatments, including immune checkpoint inhibitors, Tcell transfer therapy, monoclonal antibodies, treatment vaccines, and immune system modulators. ${ }^{1,2}$ Immunotherapy drugs are enhanced to target specific checkpoints in the immune system and the body's defense systems to tackle the most challenging oncology diseases. ${ }^{3,4}$ However, the advancement of immunotherapy still has significant obstacles, including the need for biomarkers, deficiencies of clinical design to assess safety and efficacy, the incapability to predict the response of treatment for individual patients, and high cost. ${ }^{5,6}$ The cost of cancer immunotherapy is $\$ 100,000$ or more per patient, roughly two times the United States median household annual income. ${ }^{7,8}$ Even though immunotherapy is often covered by health insurance, it can still be unaffordable to patients due to high out-of-pocket costs.

Non-Hodgkin lymphoma (NHL) starts inside white blood cells called lymphocytes that can grow in areas of the immune system, such as the lymph nodes. ${ }^{9} \mathrm{NHL}$ accounts for an estimate of 3\% for cancer-related deaths and is the seventh leading cause of new cancer cases in the United States. ${ }^{10}$ In 2020, there were 74,200 diagnosed NHL cases and 19,970 deaths from this disease. ${ }^{11}$

Acute lymphoblastic leukemia (ALL) is one of the most common types of cancer in the white blood cells by overproducing immature lymphocytes in the bone marrow diagnosed in the pediatric population. ${ }^{12}$ Children who have ALL have a high number of lymphoblasts/lymphocytes. When this occurs, the number of cancerous cells outnumber the 
number of white blood cells. ALL is a B-cell lymphoma disease that occurs from somatic genetic alterations, which include chromosome number change/rearrangement. ${ }^{13}$ Symptoms of ALL are anemia, bruising, bleeding, and fatigue. ALL is the most common cancer in children and young adults, with around $54.3 \%$ of new cases under $20 .{ }^{14}$ ALL accounts for around $20 \%$ of pediatric cancer for children. ${ }^{15}$ ALL occurs mainly in children, representing $80 \%$ of cases; however, adults can be susceptible to this disease with a low cure rate of $40 \% .^{26}$ According to the National Cancer Institute, there were over 6,100 new cases of ALL and 1,500 deaths in 2020 in the US. ${ }^{17}$

Treatment can bring $95 \%$ complete remission of patients, and since 1948, there has been a significant $80 \%$ increase in survival rate in children. ${ }^{18,19}$ However, the survival rate can drastically decrease on patients who do not respond to initial chemotherapy treatment.

Adolescent or young adults with standard-risk ALL often receive three drugs for the first month of treatment as first-line therapy. Patients with standard-risk ALL would typically receive the chemotherapy drugs L-asparaginase and vincristine and the steroid drug dexamethasone..$^{20,21}$ Treatment will vary according to the cancer risk. Patients who are relapsed or refractory need to use a second-line therapy that consists of chemotherapies such as blinatumomab and clofarabine combination (etoposide and cyclophosphamide). ${ }^{22}$ Patients who are refractory or relapsed after receiving two or more lines of systemic therapy can use tisagenlecleucel that is considered the last treatment option.

Tisagenlecleucel is indicated for adult patients with relapsed or refractory large B-cell lymphoma after two or more lines of systemic therapy, including diffuse large B-cell lymphoma (DLBCL) not otherwise specified, high-grade B-cell lymphoma, and DLBCL arising from follicular lymphoma. ${ }^{23,24}$ Tisagenlecleucel was also approved for relapsed or refractory acute 
lymphoblastic leukemia and for treating pediatric and young adult patients up to 25 years of age with B-cell acute lymphoblastic leukemia (ALL). ${ }^{25,26}$ Tisagenlecleucel is given as a single dose with a wholesale acquisition cost (WAC) of $\$ 475,000 .{ }^{27}$ Despite the high cost of new ALL treatments, studies assessing their cost-effectiveness are lacking.

Cost-effective analysis of tisagenlecleucel compared to other salvage chemotherapy treatments for relapsed-refractory ALL has not been published. Due to the limitation of clinical trials and the high cost of CAR T-cell therapies, questions have been raised on their economic and clinical value in clinical practice..$^{28}$ 


\section{OBJECTIVES}

The objective of this study is to evaluate the cost-effectiveness of tisagenlecleucel; clofarabine, etoposide, cyclophosphamide; and blinatumomab for the treatment of relapserefractory ALL for adolescent and young adult patients from the U.S. health care payer perspective. 


\section{HYPOTHESIS}

We hypothesize that tisagenlecleucel is the most cost-effective alternative for treating RRALL for adolescent and young adult patients. 


\section{MATERIALS AND METHODS}

\subsection{Data Sources}

Clinical data were collected from the FDA databases, RedBook online, National Institutes of Health (NIH) research database, PubMed database, and ClinicalTrials.gov. ${ }^{29,30}$ ClinicalTrails.gov is managed by the United States National Library of Medicine and the National Institutes of Health. ClinicalTrials.gov includes information from over 200 countries, with more than 329,000 trials to date. ${ }^{31}$

Tisagenlecleucel and salvage chemotherapy treatment AWP and WAC data were collected from the RedBook online. The information in the RedBook includes the name of the product, active ingredient, brand or generic status, price start date, orange book code, formulation, route of administration, dosage unit, average wholesale price (AWP), and wholesale acquisition cost (WAC). ${ }^{32}$ Drug manufacturers report the AWP and the WAC. These prices do not represent the actual net acquisition cost paid in the U.S. but are used for pharmacy reimbursement purposes. Other cost information was collected from previously published studies.

\subsection{Methods}

\subsection{Partitioned Survival Model}

A cost-effectiveness model using the U.S. health care payer's perspective was constructed by using TreeAge Pro (Healthcare Version) version 2021 software. The partitioned survival model (Figure 1) will consist of a cohort for specific states: remission, refractory or relapsed, and death based on overall survival. 


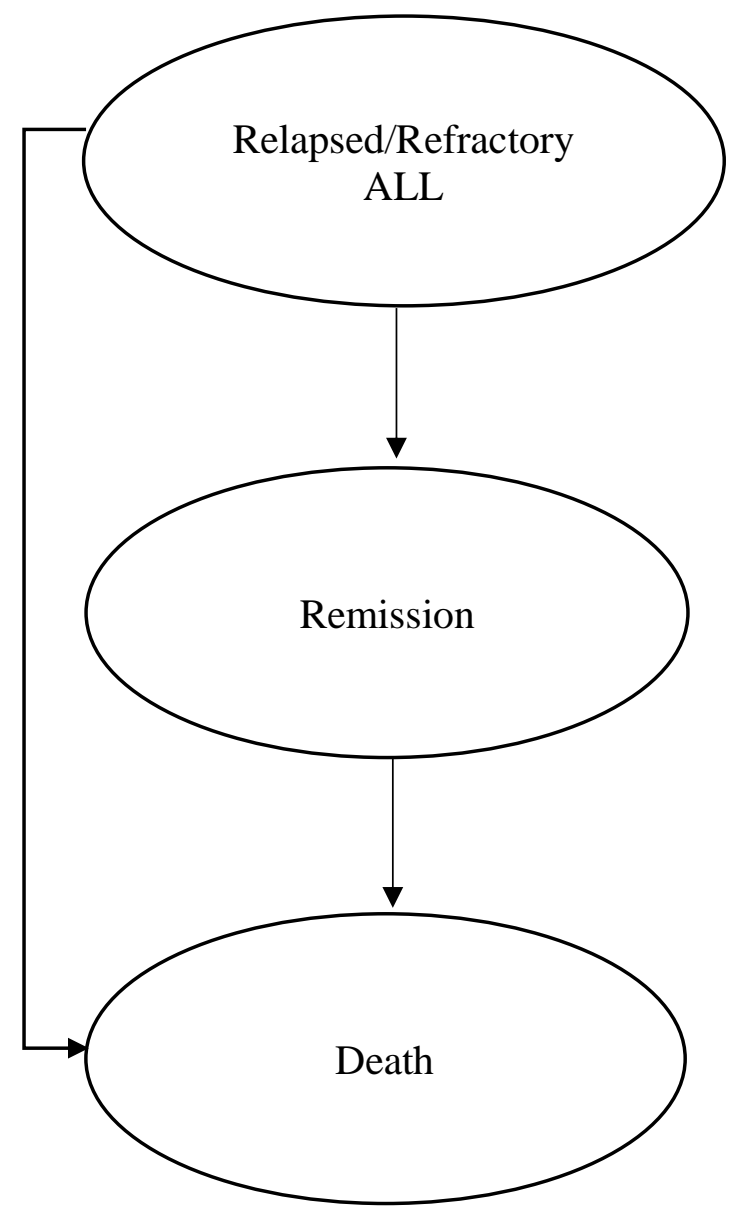

Figure 1. States of the partitioned survival model

The partitioned survival model baseline assumptions are that patients had a previous history of chemotherapy and enter the model at ten years of age. The primary study outcome was the number of life-years gained over the study time horizon. The incremental life-years gained were estimated as the difference in life-years gained between the therapeutic alternatives.

The study includes direct healthcare costs related to the alternatives. Indirect costs were excluded from the analysis. All costs were adjusted to 2020 U.S. dollars using all urban consumers, not seasonally adjusted, U.S. city average, all items, consumer price index (CPI). Costs and outcomes were discounted at a $3 \%$ annual discount rate. 
The cost and life-years gained over the time horizon were estimated for each treatment. A cost-effectiveness ratio (CER) was employed to calculate the cost per life-year gained for each treatment alternative. The lowest cost per life-year treatment was considered as the reference therapy. When a treatment had a greater cost and effectiveness in relation to the reference, an incremental cost-effectiveness ratio was performed to determine the additional cost to obtain one life-year.

The impact of parameter uncertainty was explored by a one-way sensitivity analysis on each model parameter. A probabilistic sensitivity analysis was conducted to investigate the combined impact of uncertainty of the variables included in the analysis. Random values were drawn from the chosen distributions as a second-order Monte-Carlo simulation of 1000 patients to estimate the mean and $95 \%$ confidential intervals (CI) of overall survival probabilities. All parameters in the model will have correspondingly appropriate distributions. Costs were randomly drawn from a gamma distribution; the hazard ratio was randomly sampled from a lognormal distribution. Likewise, binominal data, such as adverse events, were randomly drawn from a beta distribution.

\subsection{Treatment Strategies}

The FDA approved three products approved by the FDA for the treatment of ALL in pediatric patients (Table 1). 
Table 1. Tisagenlecleucel, blinatumomab, and clofarabine FDA-Approved Indications

\begin{tabular}{|l|l|}
\hline \multicolumn{1}{|c|}{$\begin{array}{c}\text { Generic Name } \\
\text { Approval Date) }\end{array}$} & \multicolumn{1}{c|}{ Pediatric ALL Indications } \\
\hline $\begin{array}{l}\text { Tisagenlecleucel } \\
\text { (August 30, 2017) }\end{array}$ & $\begin{array}{l}\text { Indicated for the treatment of Pediatric and Young Adult Relapsed or } \\
\text { Refractory (r/r) B-cell Acute Lymphoblastic Leukemia (ALL) patients } \\
\text { up to 25 years of age with B-cell precursor acute lymphoblastic } \\
\text { leukemia (ALL) that is refractory or in second or later relapse. }\end{array}$ \\
\hline $\begin{array}{l}\text { Blinatumomab } \\
\text { September 1, 2016) }\end{array}$ & $\begin{array}{l}\text { Indicated for the treatment of relapsed or refractory CD19-positive B- } \\
\text { cell precursor acute lymphoblastic leukemia (ALL) in adults and } \\
\text { children. }\end{array}$ \\
\hline $\begin{array}{l}\text { Clofarabine } \\
\text { December 12, 2004) }\end{array}$ & $\begin{array}{l}\text { Indicated for the treatment of pediatric patients 1 to 21 years old with } \\
\text { relapsed or refractory acute lymphoblastic leukemia after at least two } \\
\text { prior regimens. This indication is based upon response rate. There are no } \\
\text { trials verifying an improvement in disease-related symptoms or } \\
\text { increased survival with clofarabine injection. }\end{array}$ \\
\hline
\end{tabular}

The treatment dosages for tisagenlecleucel, blinatumomab, and clofarabine are described in Table 2.

$\underline{\text { Tisagenlecleucel Treatment Process }}$

To prepare tisagenlecleucel, the patient undergoes leukapheresis to obtain peripheral blood mononuclear cells. Leukapheresis treatment lasts 3 to 6 hours, and within 24 hours, the blood cells are cryopreserved (Table 3). ${ }^{32}$ Ex vivo preparation is next conducted for tisagenlecleucel with autologous T cells. The autologous $\mathrm{T}$ cells are transduced to activate T cells by a lentiviral vector. The process of preparing tisagenlecleucel takes approximately 45 days, and during this time, patients undergo bridging therapy to stop disease progression. ${ }^{32}$ Lymphodepleting chemotherapy is received by patients two weeks before the infusion of tisagenlecleucel so the patient can help the proliferation of tisagenlecleucel throughout the body. 
Table 2. Treatment dosages for tisagenlecleucel, blinatumomab, and clofarabine

\begin{tabular}{|c|c|c|}
\hline Name & Therapy & Source \\
\hline Tisagenlecleucel & $\begin{array}{l}3.1 \times 106 / \mathrm{kg}(0.2-5.4 \times 106 / \mathrm{kg}) \text { transfused viable } \mathrm{T} \\
\text { cells. }\end{array}$ & Maude et al. (2018) \\
\hline $\begin{array}{l}\text { Bridging } \\
\text { chemotherapy } \\
\text { (Given to } 87 \% \text { of } \\
\text { patients prior to } \\
\text { CART) }\end{array}$ & $\begin{array}{l}\text { Methotrexate (15mg I.T. x } 1) \text {; Hydrocortisone }(15 \mathrm{mg} \\
\text { I.T. x } 1) \text { and cytarabine ( } 30 \mathrm{mg} \text { I.T. weekly until CSF } \\
\text { clears) } \\
\left.\text { Cytarabine ( } 300 \mathrm{mg} / \mathrm{m}^{2} \mathrm{IV} \times 1\right) \text { and etoposide } \\
\left(150 \mathrm{mg} / \mathrm{m}^{2} \mathrm{IV} \times 2\right) \text { peg asparaginase ( } 25000 \text { units/ } \\
\left.\mathrm{m}^{2} \mathrm{IV} \times 1\right)\end{array}$ & Lin et al. (2018) \\
\hline $\begin{array}{l}\text { Lympho-depleting } \\
\text { chemotherapy (given } \\
\text { to } 96 \% \text { of patients } \\
\text { prior to CART) }\end{array}$ & $\begin{array}{l}\text { Fludarabine }\left(30 \mathrm{mg} / \mathrm{m}^{2} \mathrm{IV} \text { x 4), Cyclophosphamide }\right. \\
\left(500 \mathrm{mg} / \mathrm{m}^{2} \mathrm{IV} \text { x 2) }\right.\end{array}$ & Maude et al. (2018) \\
\hline $\begin{array}{l}\text { Lympho-depleting } \\
\text { chemotherapy (given } \\
\text { to } 4 \% \text { of patients } \\
\text { prior to CART) }\end{array}$ & $\begin{array}{l}\text { Cytarabine }\left(500 \mathrm{mg} / \mathrm{m}^{2} \mathrm{IV} \times 2\right) \text { and etoposide } \\
\left(150 \mathrm{mg} / \mathrm{m}^{2} \mathrm{IV} \times 3\right)\end{array}$ & Maude et al. (2018) \\
\hline Blinatumomab & $5 \mathrm{ug} / \mathrm{m}^{2} / \mathrm{d} \times 7$ days, then $15 \mathrm{ug} / \mathrm{m}^{2} / \mathrm{d}$ & $\begin{array}{l}\text { Stackelberg et al. } \\
(2016)\end{array}$ \\
\hline $\begin{array}{l}\text { Clofarabine } \\
\text { Combination }\end{array}$ & $\begin{array}{l}\text { clofarabine (400mg/ m² IV x 9days), etoposide } \\
\text { (100mg / m² IV X } 9 \text { days), cyclophosphamide } \\
\text { (440mg / } \mathrm{m}^{2} \text { x } 9 \text { days) }\end{array}$ & Hijiya et al. (2009) \\
\hline
\end{tabular}

Table 3. Treatment timeline of tisagenlecleucel

\begin{tabular}{|c|c|}
\hline Treatment & Dosage \\
\hline$\frac{\text { Bridging chemotherapy }}{\text { Days } 1-2}$ & $\begin{array}{l}\text { Methotrexate (15mg I.T. x1); Hydrocortisone } \\
(15 \mathrm{mg} \text { I.T. x1) and cytarabine ( } 30 \mathrm{mg} \text { I.T. } \\
\text { weekly until CSF clears); Cytarabine ( } 300 \mathrm{mg} / \\
\left.\mathrm{m}^{2} \mathrm{IV} \times 1\right) \text { and etoposide }\left(150 \mathrm{mg} / \mathrm{m}^{2} \mathrm{IV} \times 2\right) \\
\left.\text { peg asparaginase ( } 25000 \text { units } / \mathrm{m}^{2} \mathrm{IV} \times 1\right)\end{array}$ \\
\hline$\frac{\text { Lymphodepleting chemotherapy }}{\text { Days 3-17 }}$ & $\begin{array}{l}\text { Fludarabine }\left(30 \mathrm{mg} / \mathrm{m}^{2} \mathrm{IV} \text { x } 4\right) \text {, } \\
\left.\text { Cyclophosphamide( } 500 \mathrm{mg} / \mathrm{m}^{2} \mathrm{IV} \times 2\right)\end{array}$ \\
\hline Tisagenlecleucel & $\begin{array}{l}3.1 \times 106 / \mathrm{kg}(0.2-5.4 \times 106 / \mathrm{kg}) \text { transfused viable } \\
\text { T cells. }\end{array}$ \\
\hline
\end{tabular}


$\underline{\text { Blinatumomab and Clofarabine combination }}$

Patients who receive blinatumomab and clofarabine and are in remission also receive post-induction chemotherapy after one year to continue to be in remission (Tables 4 and 5).

Table 4. Treatment timeline for blinatumomab

\begin{tabular}{|c|c|}
\hline Cycle & Dosage \\
\hline Introduction Cycle 1 & $5 \mathrm{ug} / \mathrm{m}^{2} / \mathrm{d} / \mathrm{day}$ \\
Days 1-7 & $\begin{array}{c}15 \mathrm{ug} / \mathrm{m}^{2} / \mathrm{d} / \mathrm{day} \\
\text { Days 8-28 } \\
\text { Days 29-42 }\end{array}$ \\
\hline Induction Cycle 2 & 14-day treatment-free interval \\
Days 1-28 & $15 \mathrm{ug} / \mathrm{m}^{2} / \mathrm{d} /$ day \\
Days 29-42 & 14-day treatment-free interval \\
\hline Consolidation Cycles 3-5 & $15 \mathrm{ug} / \mathrm{m}^{2} / \mathrm{d} /$ day \\
Days 1-28 & 14-day treatment-free interval \\
Days 29-42 & $15 \mathrm{ug} / \mathrm{m}^{2} / \mathrm{d} /$ day \\
\hline Continued Cycles 6-9 & 56-day treatment-free interval \\
\hline
\end{tabular}

Table 5. Treatment timeline for clofarabine combination

\begin{tabular}{|c|c|}
\hline Cycle & Dosage \\
\hline Cycle 1 ( 9 consecutive days) & $\begin{array}{l}\text { clofarabine }\left(400 \mathrm{mg} / \mathrm{m}^{2} \mathrm{IV} \text { x 9days), }\right. \\
\text { etoposide (100mg / } \mathrm{m}^{2} \mathrm{IV} \text { X } 9 \text { days), } \\
\text { cyclophosphamide (440mg / } \mathrm{m}^{2} \text { x } 9 \text { days) }\end{array}$ \\
\hline Cycle 2 (9 consecutive days) & $\begin{array}{l}\text { clofarabine }\left(400 \mathrm{mg} / \mathrm{m}^{2} \mathrm{IV} \text { x } 9 \text { days }\right) \\
\text { etoposide }\left(100 \mathrm{mg} / \mathrm{m}^{2} \mathrm{IV} \times 9 \text { days }\right) \\
\text { cyclophosphamide ( } 440 \mathrm{mg} / \mathrm{m}^{2} \text { x } 9 \text { days) }\end{array}$ \\
\hline
\end{tabular}




\subsection{Outcomes}

Survival data were derived from three clinical trial sources Hijiya et al. (2009), Lin et al. (2018), Stackelberg et al. (2016), a study assessing the survival of ALL patients in the 10-14 years old range and survival for the general population ${ }^{33}$.

Tisagenlecleucel overall survival, continued remission, and event-free survival were obtained from Maude et al. (2018). There were two sets of data used for tisagenlecleucel:

- Efficacy analysis set: Includes patients that used the drug and excludes patients that were enrolled in the study but did not qualify for getting the drug because of death, changes in health status that resulted in exclusion, or problems manufacturing the drug.

- Enrolled set: includes all the patients enrolled in the clinical trial.

Blinatumomab clinical trial overall survival, continued remission, and event-free survival were obtained from Stackelberg et al. (2016). Clofarabine combination clinical trial overall survival curve, continued remission, and event-free survival were obtained from Hijiya et al. (2009).

Kaplan-Meier curves were created for the probability of overall survival, continued remission, and event-free survival for tisagenlecleucel, blinatumomab, and clofarabine. KaplanMeier curves were created because the estimates of survival data can deal with differing survival times since not all patients continue throughout the whole study. Also, Kaplan-Meier curves give a "time to an event" at the respective time interval. 


\subsection{Adverse Events}

The probability and cost of adverse events were collected from the literature (Table 6).

Table 6. Cost and probabilities per patient for all treatment strategies. ${ }^{12,14,24}$

\begin{tabular}{|l|r|r|r|r|}
\hline Cost and Probabilities & $\begin{array}{l}\text { Tisagenlecleucel } \\
\text { Probabilities of } \\
\text { Adverse Events }\end{array}$ & $\begin{array}{l}\text { Blinatumomab } \\
\text { Probabilities of } \\
\text { Adverse Events }\end{array}$ & $\begin{array}{l}\text { Clofarabine } \\
\text { Probabilities of } \\
\text { Adverse Events }\end{array}$ & $\begin{array}{l}\text { Cost of } \\
\text { Patient }\end{array}$ \\
\hline Acute Kidney Injury & 0.08 & 0 & 0.16 & $\$ 682.03$ \\
\hline ALT or AST Increased & 0.1 & 0.16 & 0.4 & $\$ 1,544.79$ \\
\hline Anemia & 0.4 & 0.36 & 0.64 & $\$ 4,526.60$ \\
\hline Coagulopathy & 0 & 0 & 0.12 & $\$ 296.53$ \\
\hline Cytokine Release Syndrome & 0.46 & 0.06 & 0 & $\$ 9,043.81$ \\
\hline Decreased Appetite & 0.09 & 0 & 0.2 & $\$ 445.90$ \\
\hline Febrile Neutropenia & 0.35 & 0.17 & 0.6 & $\$ 7,273.80$ \\
\hline Fluid Overload & 0.05 & 0 & 0 & $\$ 30.02$ \\
\hline Gingival Bleeding & 0 & 0 & 0.12 & $\$ 154.67$ \\
\hline Hepatomegaly & 0 & 0 & 0 & $\$ 0$ \\
\hline Hyperbilirubinemia & 0.11 & 0 & 0.12 & $\$ 209.23$ \\
\hline Hypertension & 0 & 0.06 & 0 & $\$ 41.16$ \\
\hline Hypokalemia & 0.08 & 0.17 & 0.36 & $\$ 1,322.66$ \\
\hline Hypophosphatemia & 0.08 & 0 & 0.12 & $\$ 306.26$ \\
\hline Hypotension & 0.17 & 0 & 0.24 & $\$ 818.76$ \\
\hline Hypoxia & 0.11 & 0 & 0 & $\$ 98.97$ \\
\hline Increased Lipase & 0 & 0 & 0.2 & $\$ 275.98$ \\
\hline Leukopenia & 0.12 & 0.1 & 0.16 & $\$ 286.82$ \\
\hline Nausea & 0 & 0 & 0.12 & $\$ 111.64$ \\
\hline Neutropenia & 0.04 & 0.17 & 0.52 & $\$ 4,279.79$ \\
\hline Overall Neurological Events & 0.13 & 0.04 & 0 & $\$ 323.20$ \\
\hline Pleural Effusion & 0.04 & 0 & 0 & $\$ 51.27$ \\
\hline Pulmonary Edema & 0.06 & 0 & 0.12 & $\$ 192.22$ \\
\hline Pyrexia & 0.1 & 0.14 & 0.16 & $\$ 260.28$ \\
\hline Rash & 0 & 0 & 0.64 & $\$ 4,416.20$ \\
\hline Respiratory Distress & 0.05 & 0.12 & $\$ 60.01$ \\
\hline Thrombocytopenia & 0 & 0.12 & $\$ 259.44$ \\
\hline Typhilis & & 0 & \\
\hline Veno Occlusive Disease & 0 & 0 & \\
\hline
\end{tabular}




\subsection{Costs}

Costs were acquired from the Red Book, Centers for Medicare and Medicaid Services, and adjusted to 2020 dollars by the consumer price index (CPI). The direct medical costs include drug administration, drug product, follow-up care, and adverse events (Tables 7-11).

Table 7. Tisagenlecleucel healthcare costs

\begin{tabular}{|c|c|c|c|}
\hline Pre-tisagenlecleucel & & Cost & Source \\
\hline Bridging chemotherapy & $\begin{array}{l}\text { Drug and administration at } \\
\text { the hospital }\end{array}$ & $\$ 15,000.00$ & Lin et al. (2018) \\
\hline $\begin{array}{l}\text { Lymphodepleting chemotherapy } \\
\text { (fludarabine and } \\
\text { cyclophosphamide) } 96 \% \text { patients }\end{array}$ & $\begin{array}{l}\text { Drug and administration at } \\
\text { hospital }\end{array}$ & $\$ 1,781.49$ & CMS (2018) \\
\hline $\begin{array}{l}\text { Lymphodepleting chemotherapy } \\
\text { (cytarabine and etoposide) } 4 \% \text { of } \\
\text { patients }\end{array}$ & $\begin{array}{l}\text { Drug and administration at } \\
\text { the hospital }\end{array}$ & $\$ 807.78$ & CMS (2018) \\
\hline \multirow[t]{5}{*}{ Treatment cost } & Drug & $\$ 475,000.00$ & Red Book (2021) \\
\hline & Adverse events & $\$ 42,769.98$ & CMS (2018) \\
\hline & IVIG treatment & $\$ 28,818.24$ & $\begin{array}{l}\text { Red Book (2018); } \\
\text { Lin et al. (2018) }\end{array}$ \\
\hline & $\begin{array}{l}\text { Drug Administration at } \\
\text { hospital }\end{array}$ & $\$ 6,331.28$ & $\begin{array}{l}\text { CMS (2018); } \\
\text { Lin et al.(2018) }\end{array}$ \\
\hline & $\begin{array}{l}\text { Health care costs after } \\
\text { treatment per month }\end{array}$ & $\$ 8,056.01$ & \\
\hline Total Cost & & $\$ 578,564.78$ & \\
\hline
\end{tabular}

Table 8. Clofarabine combination healthcare costs

\begin{tabular}{|l|l|r|l|}
\hline \multirow{5}{*}{ Treatment Cost } & & \multicolumn{1}{c|}{ Cost } & \multicolumn{1}{c|}{ Source } \\
\cline { 2 - 4 } & Drug & $\$ 37,400.00$ & Lin et al. (2018) \\
\cline { 2 - 4 } & Adverse events & $\$ 54,252.52$ & $\begin{array}{l}\text { Lin et al. (2018); } \\
\text { CMS (2018) }\end{array}$ \\
\cline { 2 - 4 } & Administration at hospital & $\$ 24,342.68$ & Lin et al. (2018) \\
\cline { 2 - 4 } & $\begin{array}{l}\text { Health care costs after } \\
\text { treatment per month }\end{array}$ & $\$ 1,964.88$ & Lin et al. (2018) \\
\hline Total Cost & & $\$ 117,960.08$ & \\
\hline
\end{tabular}


Table 9. Blinatumomab healthcare costs.

\begin{tabular}{|l|l|r|l|}
\hline & & Cost & \multicolumn{1}{|c|}{ Source } \\
\hline \multirow{3}{*}{ Treatment Cost } & Drug & $\$ 43,700.00$ & Lin et al. (2018) \\
\cline { 2 - 4 } & Adverse events & $\$ 16,919.80$ & Lin et al. (2018); CMS (2018) \\
\cline { 2 - 4 } & $\begin{array}{l}\text { Administration at } \\
\text { hospital }\end{array}$ & $\$ 8,187.00$ & Lin et al. (2018) \\
\hline Total Cost & & $\$ 68,806.80$ & \\
\hline
\end{tabular}

Table 10. Cost of palliative chemotherapy for relapsed/refractory patients.

\begin{tabular}{|l|l|c|c|}
\hline & & Cost & Source \\
\hline Palliative Chemotherapy & Drug & $\$ 2,881.82$ & Lin et al. \\
\hline
\end{tabular}

Table 11. Cost of individual grade 3-4 adverse events for each treatment strategy.

\begin{tabular}{|c|c|c|c|}
\hline Adverse Event & $\begin{array}{c}\text { Tisagenlecleucel } \\
\text { Cost }\end{array}$ & $\begin{array}{c}\text { Blinatumomab } \\
\text { Cost }\end{array}$ & $\begin{array}{l}\text { Clofarabine } \\
\text { Cost }\end{array}$ \\
\hline Acute Kidney Injury & $\$ 1,706.04$ & $\$ 0$ & $\$ 3,412.08$ \\
\hline ALT or AST Increased & $\$ 790.21$ & $\$ 1,264.33$ & $\$ 3,160.84$ \\
\hline Anemia & $\$ 2,591.02$ & $\$ 2,331.92$ & $\$ 4,145.63$ \\
\hline Coagulopathy & $\$ 0$ & $\$ 0$ & $\$ 2,472.47$ \\
\hline Cytokine Release Syndrome & $\$ 19,342.28$ & $\$ 2,522.91$ & $\$ 0$ \\
\hline Decreased Appetite & $\$ 834.78$ & $\$ 0$ & $\$ 1,855.07$ \\
\hline Febrile Neutropenia & $\$ 4,980.92$ & $\$ 2,419.30$ & $\$ 8,538.71$ \\
\hline Fluid Overload & $\$ 600.65$ & $\$ 0$ & $\$ 0$ \\
\hline Gingival Bleeding & $\$ 0$ & $\$ 0$ & $\$ 1,289.62$ \\
\hline Hepatomegaly & $\$ 0$ & $\$ 0$ & $\$ 0$ \\
\hline Hyperbilirubinemia & $\$ 868.99$ & $\$ 0$ & $\$ 947.99$ \\
\hline Hypertension & $\$ 0$ & $\$ 686.40$ & $\$ 0$ \\
\hline Hypokalemia & $\$ 642.04$ & $\$ 1,364.33$ & $\$ 2,889.16$ \\
\hline Hypophosphatemia & $\$ 1,178.58$ & $\$ 0$ & $\$ 1,767.87$ \\
\hline Hypotension & $\$ 1,610.02$ & $\$ 0$ & $\$ 2,272.97$ \\
\hline Hypoxia & $\$ 900.21$ & $\$ 0$ & $\$ 0$ \\
\hline Increased Lipase & $\$ 0$ & $\$ 0$ & $\$ 1,380.66$ \\
\hline Leukopenia & $\$ 688.76$ & $\$ 573.96$ & $\$ 918.34$ \\
\hline
\end{tabular}


Table 11. Cost of individual grade 3-4 adverse events for each treatment strategy (Cont.)

\begin{tabular}{|c|c|c|c|}
\hline Nausea & $\$ 0$ & $\$ 0$ & $\$ 930.83$ \\
\hline Neutropenia & $\$ 569.25$ & $\$ 2,419.30$ & $\$ 7,400.22$ \\
\hline Overall Neurological Events & $\$ 2,272.37$ & $\$ 699.19$ & $\$ 0$ \\
\hline Pleural Effusion & $\$ 1,282.46$ & $\$ 0$ & $\$ 0$ \\
\hline Pulmonary Edema & $\$ 641.07$ & $\$ 0$ & $\$ 1,282.15$ \\
\hline Pyrexia & $\$ 471.79$ & $\$ 660.51$ & $\$ 754.86$ \\
\hline Rash & $\$ 0$ & $\$ 0$ & $\$ 0$ \\
\hline Respiratory Distress & $\$ 313.94$ & $\$ 78.49$ & $\$ 0$ \\
\hline Thrombocytopenia & $\$ 484.29$ & $\$ 2,034.01$ & $\$ 6,198.89$ \\
\hline Typhilis & $\$ 0$ & $\$ 0$ & $\$ 500.39$ \\
\hline Veno Occlusive Disease & $\$ 0$ & $\$ 0$ & $\$ 2,163.20$ \\
\hline TOTAL & $\$ 42,769.66$ & $\$ 17,054.65$ & $\$ 54,281.95$ \\
\hline
\end{tabular}




\section{RESULTS}

\subsection{Patient Characteristics}

The patient characteristics varied according to the clinical trial. Tisagenlecleucel patients were between 3 to 21 years of age (Table 12). There were $47 \%$ females and $53 \%$ males in the clinical trial. There were 92 patients enrolled in the study, and 75 underwent infusion

Table 12. Patient population of tisagenlecleucel clinical trial data (ELIANA). ${ }^{12}$

\begin{tabular}{|c|c|c|c|}
\hline Patient Population tisagenlecleucel & $\begin{array}{l}\text { Efficacy } \\
\text { Analysis Set } \\
(n=107)\end{array}$ & $\begin{array}{l}\text { Enrolled Set } \\
(n=92)\end{array}$ & $\begin{array}{l}\text { Underwent } \\
\text { Infusion }(n=75)\end{array}$ \\
\hline \multicolumn{4}{|l|}{$\begin{array}{l}\text { 0-45 days before receiving } \\
\text { tisagenlecleucel }\end{array}$} \\
\hline Dropout/Censored & - & $10(11)$ & - \\
\hline Death & - & $7(8)$ & - \\
\hline \multicolumn{4}{|l|}{ After receiving tisagenlecleucel } \\
\hline Dropout/Censored & - & - & $16(21)$ \\
\hline Death & - & - & $11(15)$ \\
\hline \multicolumn{4}{|l|}{ Age, years } \\
\hline 3 to 21 & $107(100)$ & $92(100)$ & $75(100)$ \\
\hline \multicolumn{4}{|l|}{ Sex } \\
\hline Female & - & - & $35(47)$ \\
\hline Male & - & - & $40(53)$ \\
\hline \multicolumn{4}{|l|}{ Status } \\
\hline Relapse/Refractory & - & - & $9(12)$ \\
\hline Remission & - & - & $61(81)$ \\
\hline Prior HSCT & - & - & $46(61)$ \\
\hline
\end{tabular}


Table 13. Patient population of blinatumomab clinical trials $(n=70) .{ }^{24}$

\begin{tabular}{|l|c|}
\hline Variable & n (\%) \\
\hline Sex & $47(67)$ \\
\hline Male & $25(33)$ \\
\hline Female & \\
\hline Age group, years & $10(14)$ \\
\hline$<2$ & $20(29)$ \\
\hline 2 to 6 & $40(57)$ \\
\hline 7 to 17 & \\
\hline Prevous HSCT & $40(57)$ \\
\hline Yes & $30(43)$ \\
\hline No & \\
\hline Previous Relapses & $2(3)$ \\
\hline 0 & $31(44)$ \\
\hline 1 & $29(41)$ \\
\hline 2 & $8(11)$ \\
\hline$\geq 3$ & \\
\hline Status & $39(56)$ \\
\hline Relapse/Refractory & $27(39)$ \\
\hline Remission & $16(23)$ \\
\hline Dropout/Censored & $27(39)$ \\
\hline Death & \\
\hline & \\
\hline
\end{tabular}

Blinatumomab patient age range was less than 2 years to 17 years (Table 13). The patient population of blinatumomab was $67 \%$ male and $33 \%$ female, with 70 total patients enrolled.

Clofarabine combination patients were between 1 year to 21 years of age (Table 14). The patient population was $64 \%$ male and $36 \%$ female, with 25 patients enrolled. 
Table 14. Patient population of clofarabine with etoposide and cyclophosphamide clinical trials $(\mathrm{N}=25) .{ }^{12}$

\begin{tabular}{|l|c|}
\hline Characteristic & n (\%) \\
\hline Age (years) & 14 \\
\hline Median & 1 to 21 \\
\hline Range & \\
\hline Sex & $16(64)$ \\
\hline Male & $9(36)$ \\
\hline Female & \\
\hline Prior regimens & 2 \\
\hline Median & 1 to 3 \\
\hline Range & $4(16)$ \\
\hline 1 regimen & $14(56)$ \\
\hline 2 regimen & $15(60)$ \\
\hline 3 regimen & \\
\hline Status & $15(60)$ \\
\hline Relapse/Refractory & $7(28)$ \\
\hline Remission & $4(16)$ \\
\hline Prior HSCT & $2(8)$ \\
\hline Dropout/Censored & $7(28)$ \\
\hline Death &
\end{tabular}




\subsection{Outcomes}

Tisagenlecleucel Kaplan-Meier plot (Figure 2) 95\% confidence interval at month 26 was 0.421[0.203, 0.626]. Blinatumomab Kaplan-Meier plot (Figure 3) 95\% confidence interval at month 26 was $0.246[0.146,0.359]$. Clofarabine combination (Figure 4) 95\% confidence interval at month 36 was $0.211[0.0533,0.439]$. The partitioned model survival curves are displayed in figures 5-7.

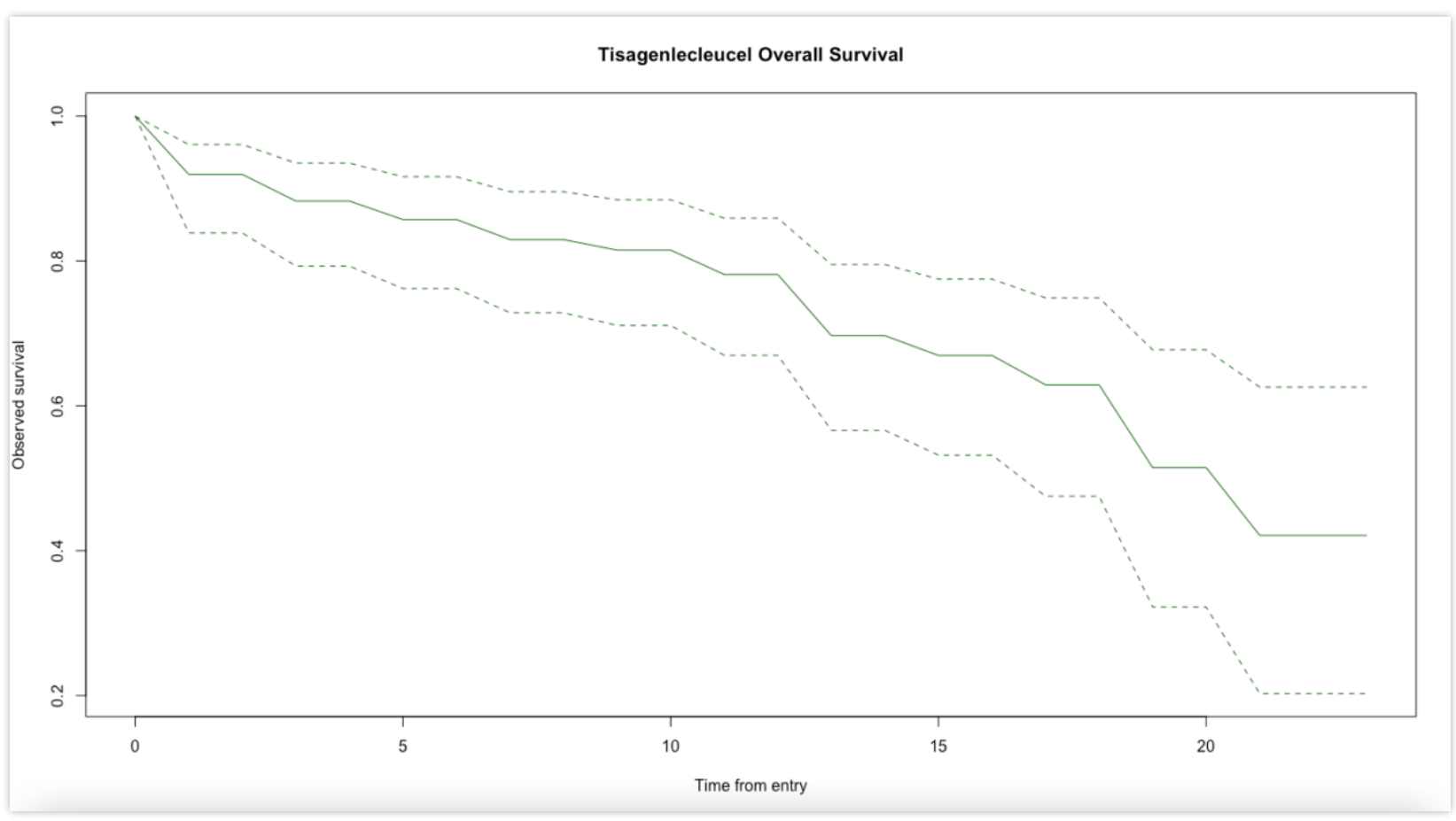

Figure 2. Tisagenlecleucel overall patient survival. ${ }^{12}$ 


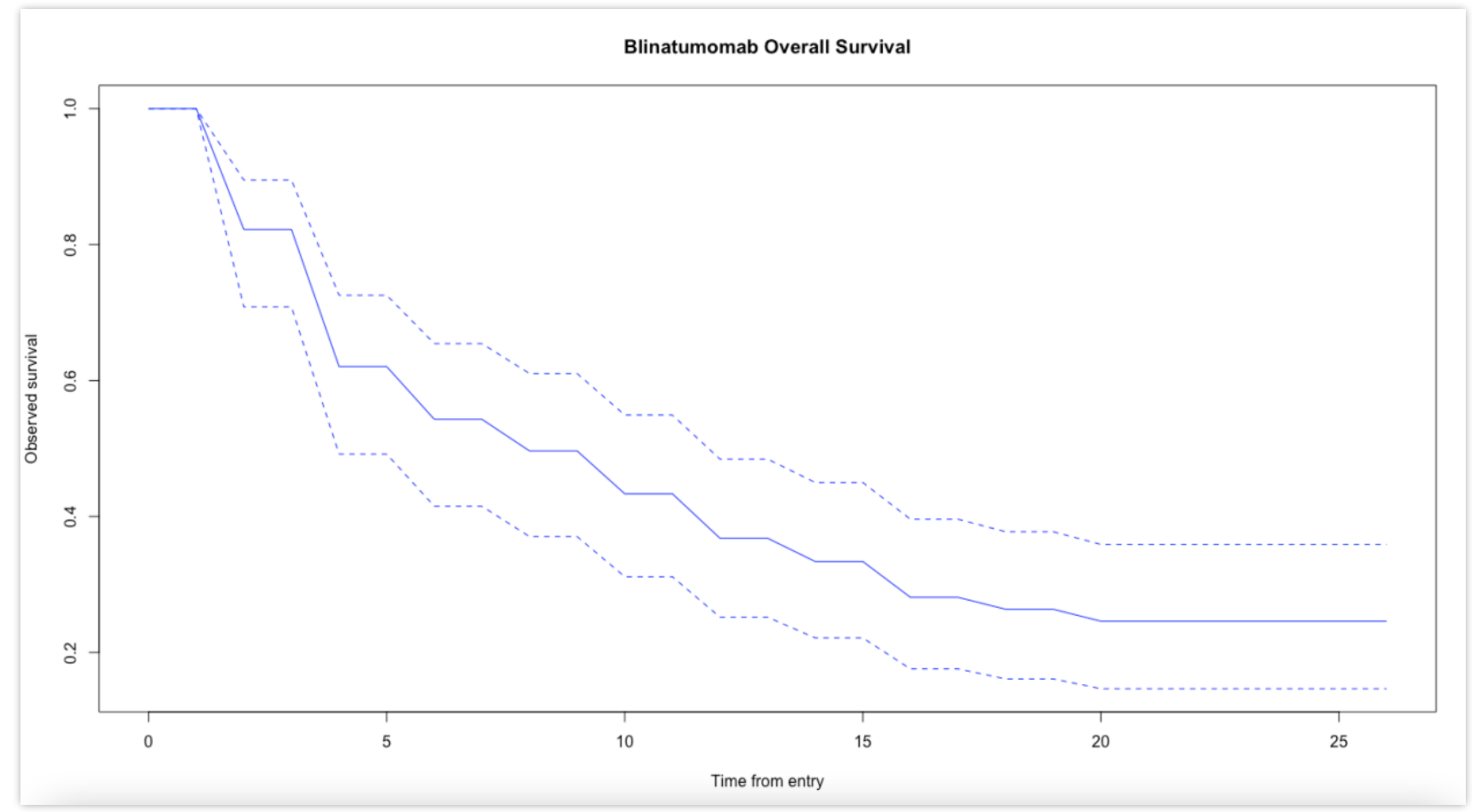

Figure 3. Blinatumomab overall patient survival. ${ }^{24}$

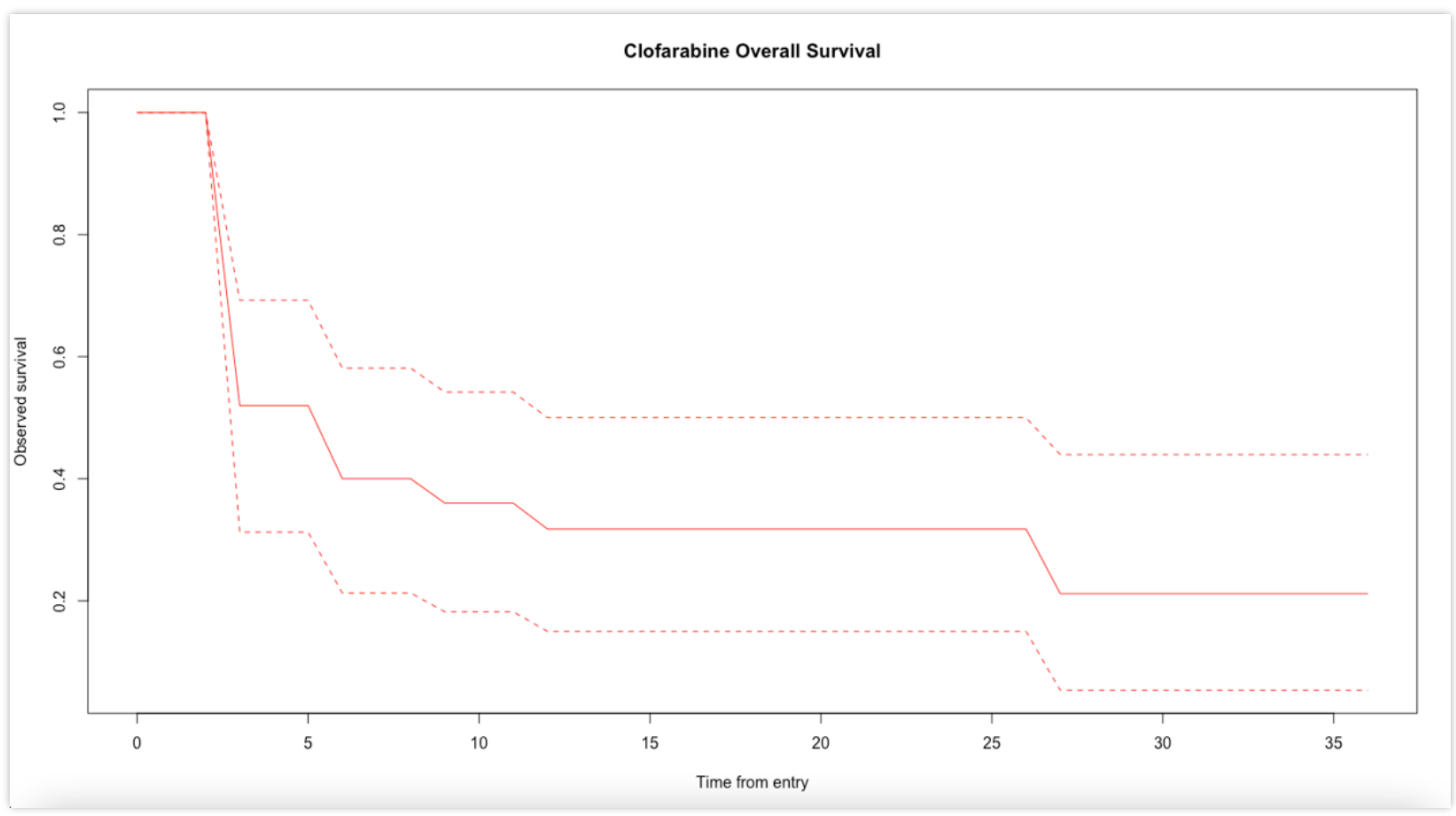

Figure 4. Clofarabine overall patient survival. ${ }^{12}$ 


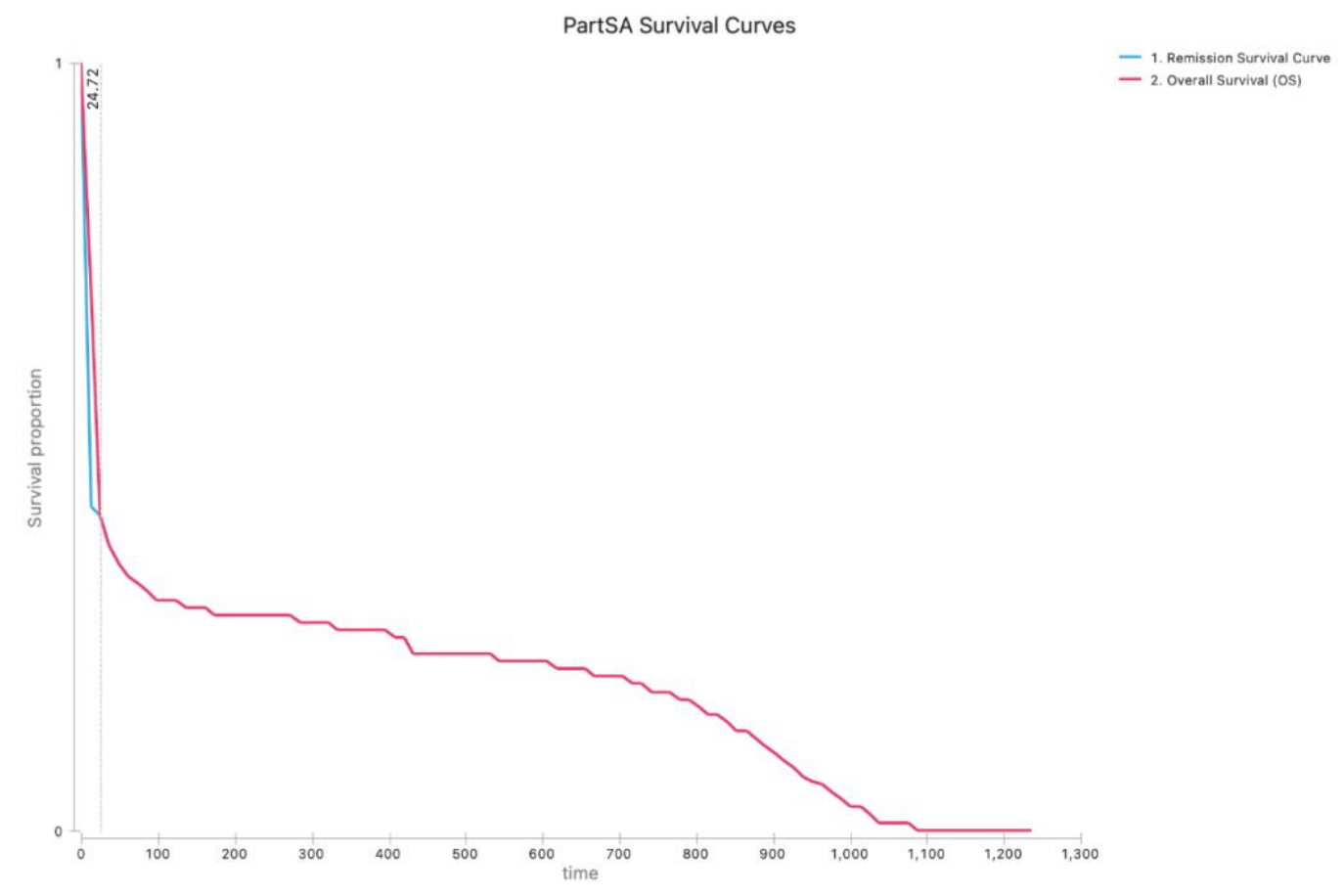

Figure 5. Partitioned survival model curve of tisagenlecleucel.

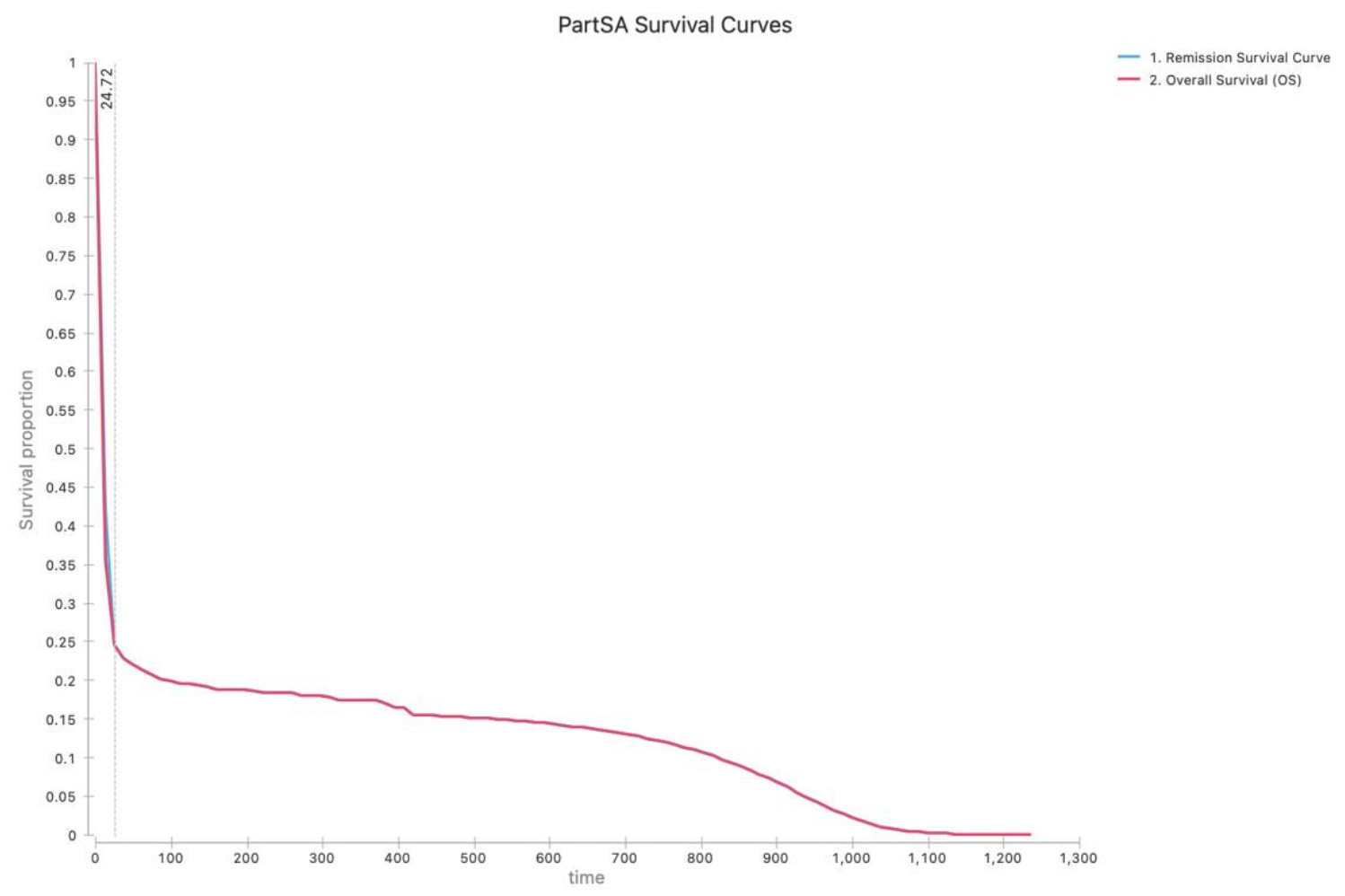

Figure 6. Partitioned survival model curve of blinatumomab. 


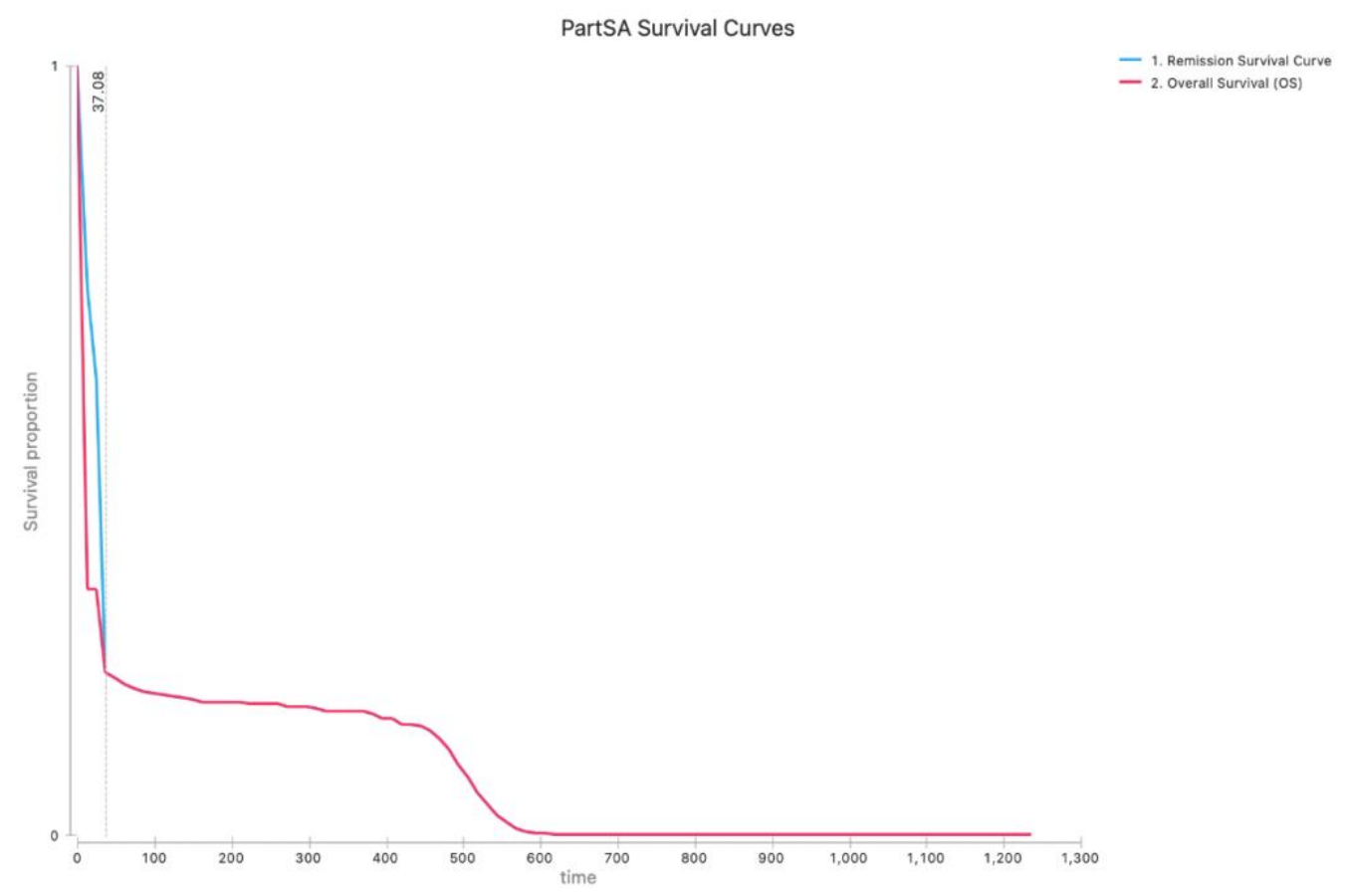

Figure 7. Partitioned survival model curve of clofarabine combination.

\subsection{Cost-Effectiveness and Incremental Cost-Effectiveness}

In the base case scenario, tisagenlecleucel effectiveness was 19.284 years, blinatumomab was 12.580 years, and clofarabine combination was 7.566 years. Blinatumomab and tisagenlecleucel were both undominated, and the clofarabine combination was dominated (Table $15)$.

A partitioned survival analysis model followed the patient cohort thought time as they moved through relapsed/refractory or remission states for tisagenlecleucel, blinatumomab, and clofarabine combination. The cost-effectiveness analysis showed that clofarabine was not costeffective (Figure 8). 
Table 15. Incremental cost, incremental effectiveness, ICER for tisagenlecleucel, blinatumomab, and clofarabine combination

\begin{tabular}{|l|r|l|r|r|r|}
\hline Drugs & \multicolumn{1}{|l|}{ Cost } & $\begin{array}{l}\text { Incremental } \\
\text { Cost }\end{array}$ & Effectiveness & $\begin{array}{l}\text { Incremental } \\
\text { Effectiveness }\end{array}$ & ICER \\
\hline Excluding Dominated & $\$ 71,701$ & & 12.580 & & \\
\hline Blinatumomab & $\$ 591,751$ & $\$ 520,050$ & 19.284 & 6.704 & $\$ 77,573$ \\
\hline Tisagenlecleucel & \multicolumn{5}{|l|}{} \\
\hline All Therapies & & 12.580 & & \\
\hline Blinatumomab & $\$ 71,701$ & & 7.566 & -5.014 & $-\$ 13,467$ \\
\hline Clofarabine & $\$ 139,225$ & $\$ 67,524$ & 19.284 & 6.704 & $\$ 77,573$ \\
\hline Tisagenlecleucel & $\$ 591,751$ & $\$ 520,050$ & 19.28 &
\end{tabular}

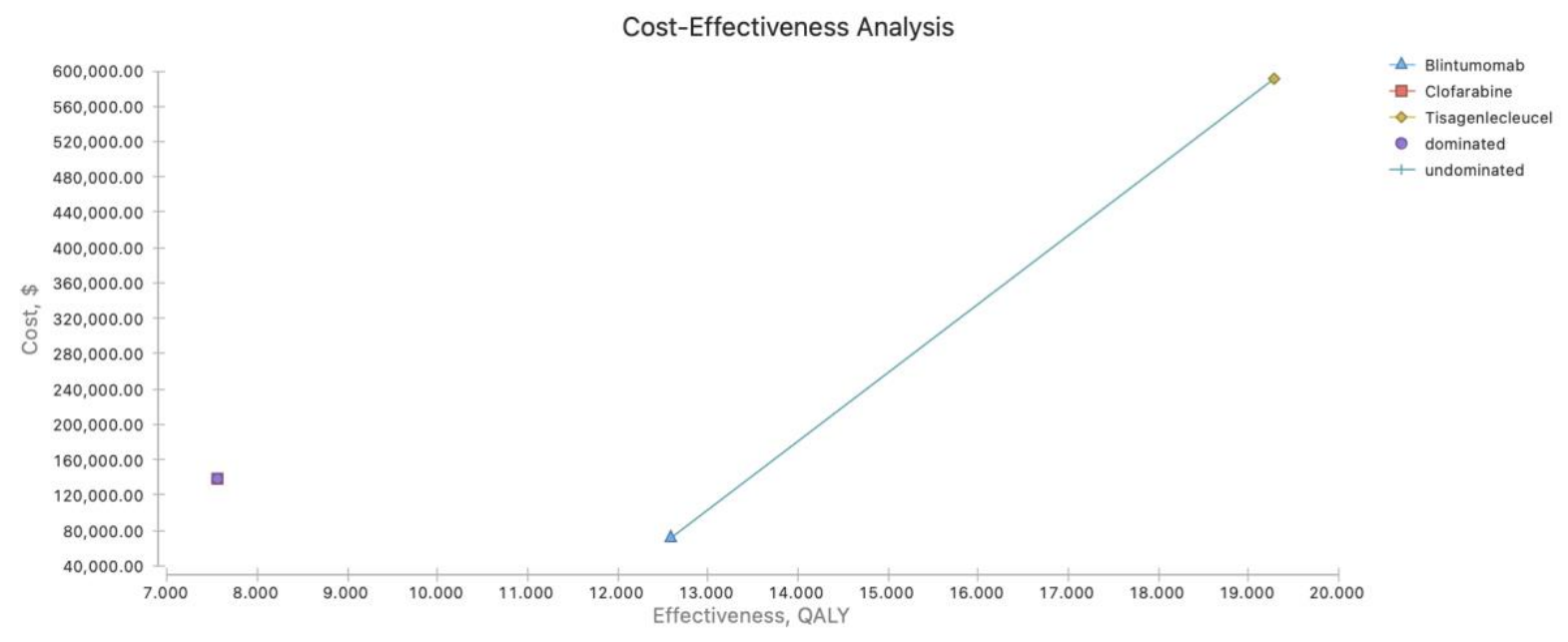

Figure 8. Cost-effectiveness analysis results for all treatments. 


\subsection{Probabilistic Sensitivity Analysis}

The PSA was conducted using the $95 \%$ confidence intervals for the overall survival and remission for all treatments. Clofarabine was dominated while tisagenlecleucel and blinatumomab remained the strategy with the higher cost and effectiveness. The PSA found that tisagenlecleucel was more cost-effective $63.1 \%$ and blinatumomab $35.8 \%$ of the time.

The PSA results found that tisagenlecleucel and blinatumomab were both undominated, and clofarabine combination was dominated. The PSA found that tisagenlecleucel was costeffective $63.1 \%$ of the time with a willingness to pay $\$ 100,000$. Even though tisagenlecleucel was more cost-effective, blinatumomab was more cost-effective 35.8\% of the time (Figure 9-12).

The Monte Carlo acceptability at the WTP of 100,000 showed that tisagenlecleucel was more cost-effective $63.1 \%$ of the time when compared to blinatumomab (35.8\%) and clofarabine (1.9\%) (Figure 13). According to the cost-effectiveness acceptability curve for the WTP, tisagenlecleucel was more favorable at a WTP higher than $\$ 80,000$. The blinatumomab WTP was more favorable below a WTP of 80,000, and clofarabine was not favorable under any WTP. 


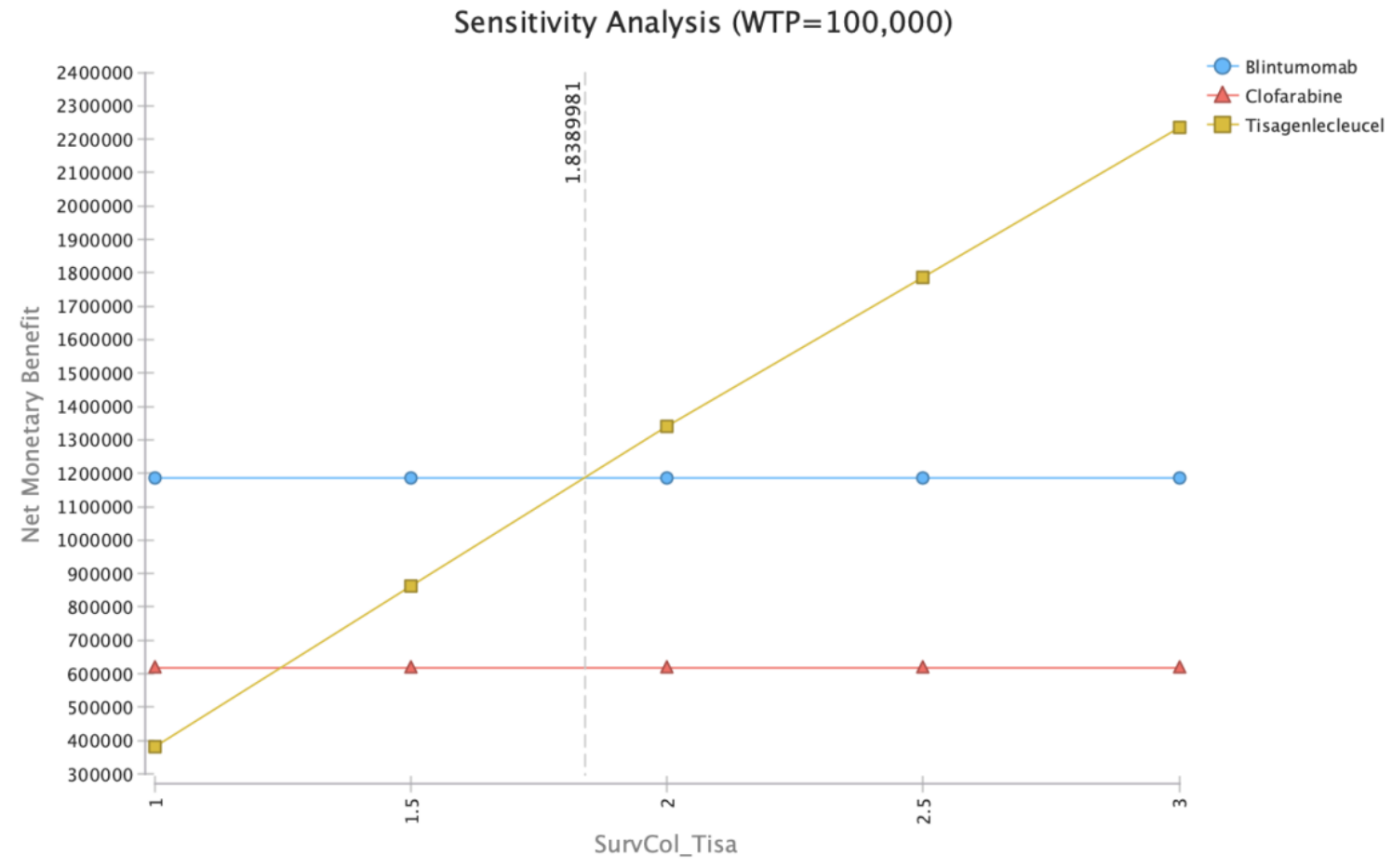

Figure 9. One-way cost-effectiveness sensitivity analysis of tisagenlecleucel

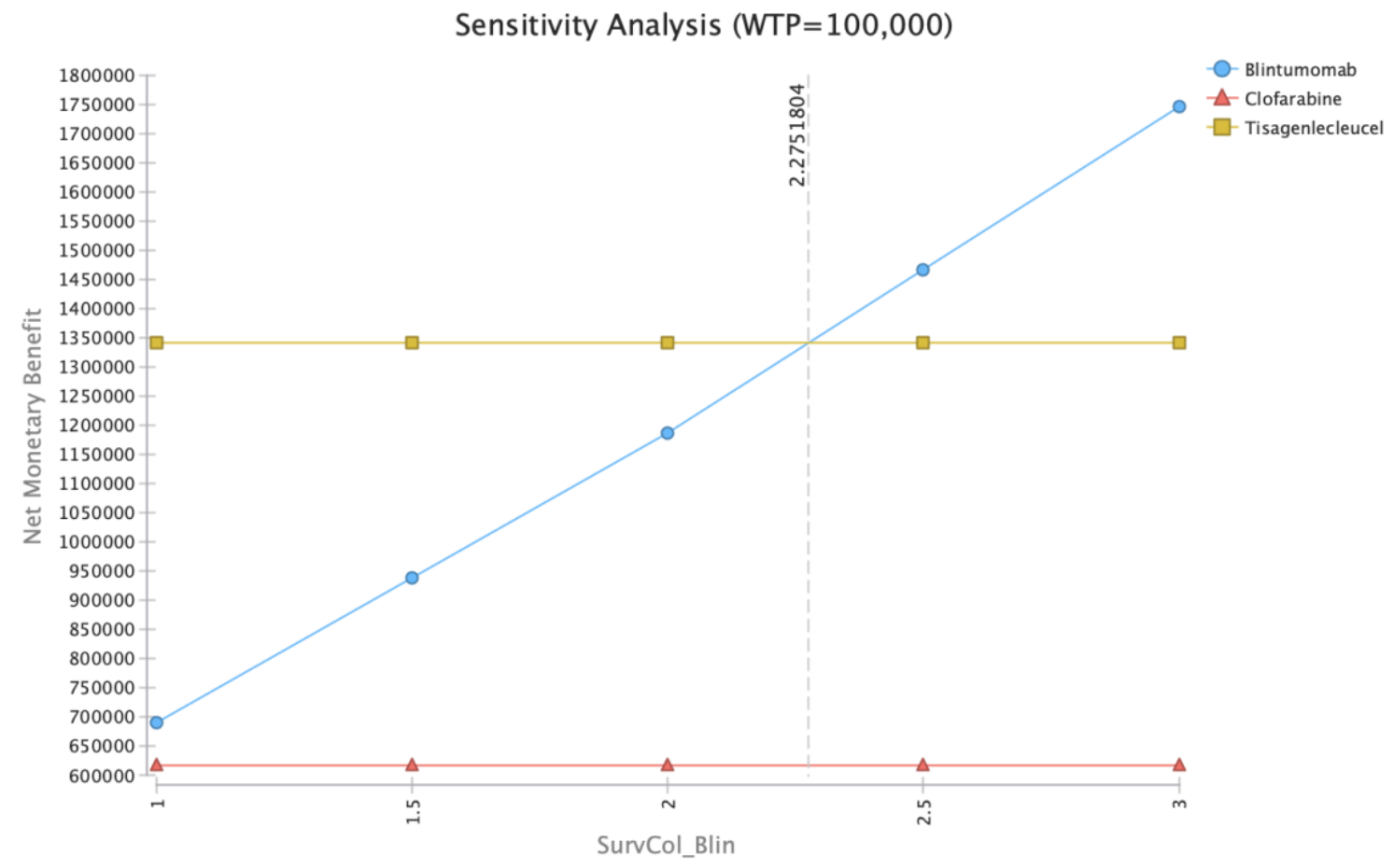

Figure 10. One-way cost-effectiveness sensitivity analysis of blinatumomab 


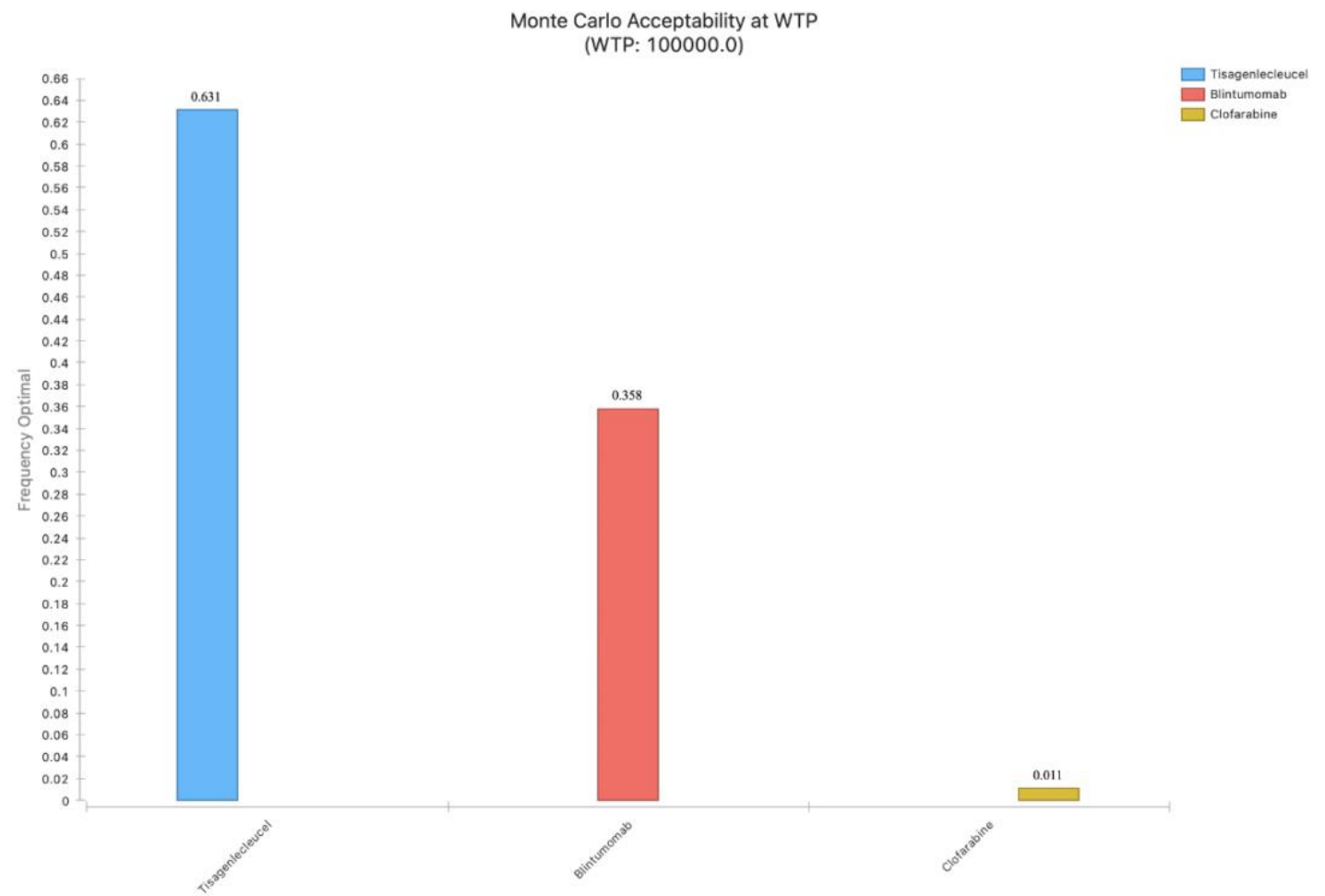

Figure 11. Monte Carlo acceptability at WTP of $\mathbf{1 0 0 , 0 0 0}$ for all treatment alternatives

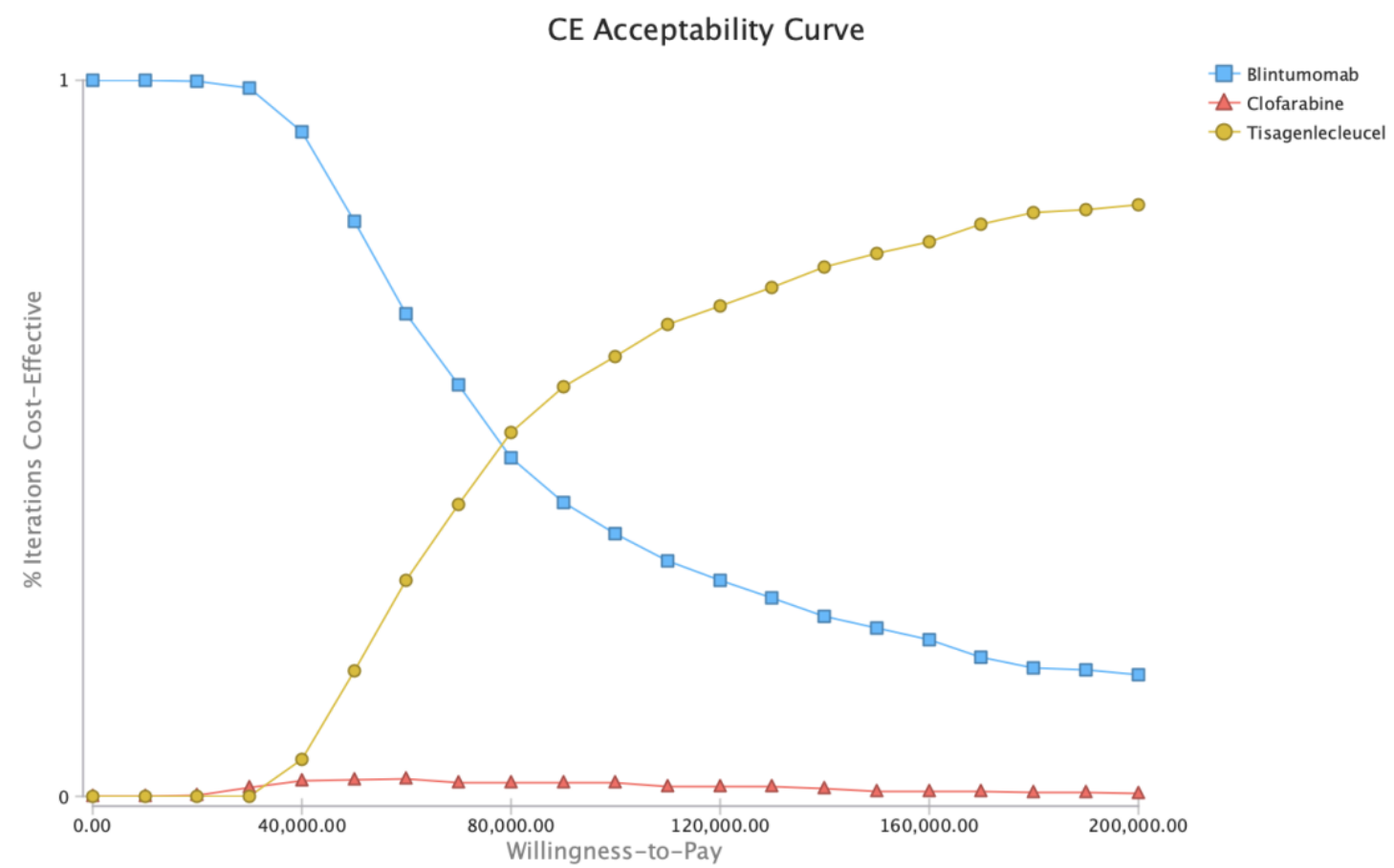

Figure 12. Cost-effectiveness acceptability curve of tisagenlecleucel, blinatumomab, and clofarabine. 


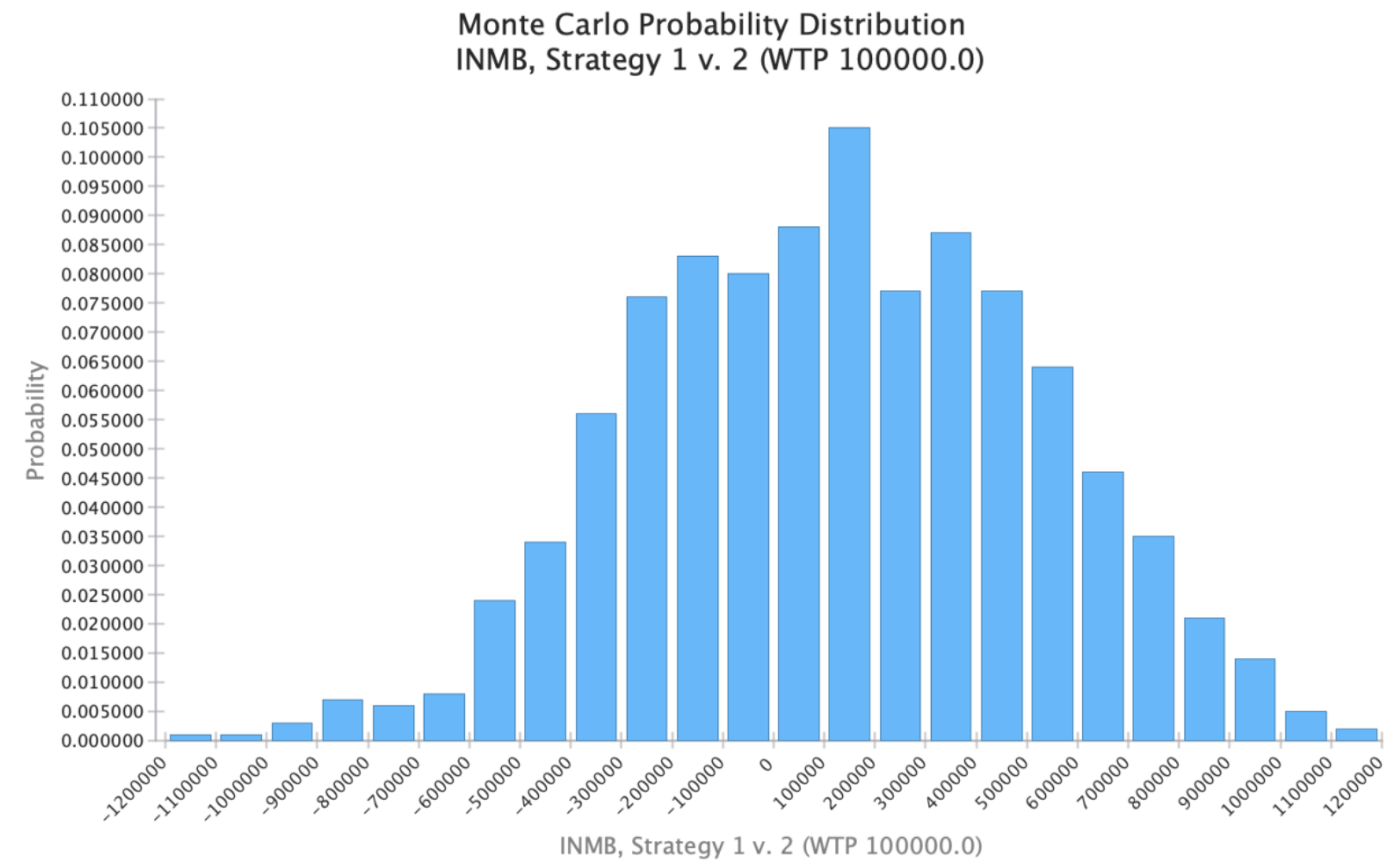

Figure 13. Monte Carlo probability distribution INMB of tisagenlecleucel vs. blinatumomab. 


\section{DISCUSSION}

Our analysis indicates that tisagenlecleucel has higher overall survival than blinatumomab and clofarabine combination in patients with ALL.

This study presented that the effectiveness for tisagenlecleucel was 19.284 and had an ICER of $\$ 77,573$ for an additional L.Y. gained. Blinatumomab had an effectiveness of 12.580, and the dominated treatment clofarabine had an effectiveness of 7.566. Tisagenlecleucel had the highest cost in the partitioned survival model, with $\$ 591,751$ and an ICER of $\$ 77,573$.

Tisagenlecleucel and blinatumomab were both undominated, and the clofarabine combination was dominated for the base case analysis. The probabilistic sensitivity analysis confirmed that tisagenlecleucel and blinatumomab were undominated, and the clofarabine combination was dominated.

According to the probabilistic sensitivity analysis, tisagenlecleucel was the most costeffective alternatives $63.1 \%$ of the time. These results are similar to those of other studies that also found that tisagenlecleucel was more cost-effective the majority of the time (Furzer et al., 2020). Clofarabine was dominated by tisagenlecleucel and blinatumomab and was the least costeffective as found in previously published studies (Locatelli et al, 2009).

The available evidence about the cost, efficacy, and safety of tisagenlecleucel, blinatumomab and clofarabine is very limited. There is a need for more studies evaluating the long-term effect of the available therapies for the treatment of ALL to get the evidence necessary for the appropriate utilization of those expensive drugs. 


\section{LIMITATIONS}

This study has some limitations. The model evaluates differences of alternative therapy pathways from a set of assumptions and does not portray the progression of RR-ALL patients in clinical practice. Patients can develop RR-ALL during their lifetime. The available data only contains outcomes for up to 34 months. Since the clinical trials are still ongoing, other clinical information on outcomes and safety was collected from published studies from the United States and other countries. The clinical trials used in this study had different disease states, previous treatments, and patient demographic characteristics. The difference is significant for age because survival rates decline with the increase in age. ${ }^{30}$

The patient characteristics included in this study were different for the clinical trials of the products tisagenlecleucel, blinatumomab, and clofarabine. The clinical trials for blinatumomab and clofarabine included patients less than 2 years of age, unlike while the clinical trials for tisagenlecleucel included patients starting at 3 years of age. The disease states of the patients included in the clinical trials were also different, with tisagenlecleucel clinical trials having a higher percentage of patients in remission at the start of the study (Table 14). Nonhealth care and indirect costs were excluded from the analysis. The life years were not adjusted by the quality of life (quality-adjusted life years) due to the limitations of the clinical trials and lack of information about the qualify of life. 


\section{CONCLUSIONS}

The base case showed that tisagenlecleucel effectiveness was the highest at 19.284, and blinatumomab was the second-highest at 12.580. Tisagenlecleuel was cost-effective with an ICER of $\$ 77,573$. Clofarabine was dominated and was the worst out of the three treatment strategies for cost-effectiveness. The results of the PSA showed that tisagenlecleucel was always not the most cost-effective. Blinatumomab was more cost-effective when it was $35.8 \%$ higher than the base case. Tisagenlecleuel was more cost-effective at a higher WTP, and blinatumomab was more cost-effective at a lower WTP. Tisagenlecleucel was more cost-effective $63.1 \%$ of the time, and blinatumomab was more cost-effective $35.8 \%$ of the time. 


\section{REFERENCES}

1. Carlson L, Ho P, Smith M, et al: Pediatric phase I drug tolerance: A review and comparison of recent adult and pediatric phase I trials. J Pediatric Hematology Oncology 1996;18:250-256, 1996

2. Lin, J., Lerman, B., Barnes, J., Boursiquot, B., Tan, Y., Robinson, A., GoldhaberFiebert, J. Cost Effectiveness of Chimeric Antigen Receptor T-Cell Therapy in Relapsed or Refractory Pediatric B-Cell Acute Lymphoblastic Leukemia. J. Clin. Oncol 2018;10;36(32):3192-3202.

3. National Cancer Institute. Acute Lymphocytic Leukemia - Cancer Stat Facts. Available at: https://seer.cancer.gov/statfacts/html/alyl.html (Accessed January 8, 2021).

4. Locatelli F, Testi AM, Bernardo ME, et al. clofarabine, cyclophosphamide and etoposide as single-course reinduction therapy for children with refractory/multiple relapsed acute lymph0blastic leukaemia. Br J Haematol 2009;147(3): 371-378.

5. Abramson JS, Palomba ML, Gordon LI, et al. C.R. rates in relapsed/refractory (R/R) aggressive B-NHL treated with the CD19- directed CAR T-cell product JCAR017 (TRANSCEND NHL 001) [abstract]. J Clin Oncol 2017;35: Suppl 15: 7513.

6. Awasthi R, Mueller KT, Yanik GA, et al Considerations for tisagenlecleucel dosing rationale [abstract]. J Clin Oncol 2018;36(15 suppl):e15056.

7. Awasthi R, Pacaud L, Waldron E, et al. Tisagenlecleucel cellular kinetics, dose, and immunogenicity in relation to clinical factors in relapsed/refractory DLBCL. Blood $A d v$ 2020;4(3):560-572. 
8. Centers for Medicare \& Medicaid Services. Available at:

https://www.cms.gov/Regulations-and-Guidance/Administrative-Simplification/CodeSets (Accessed March 1, 2021).

9. Cheson B, Vena D, Foss F, et al: Neurotoxicity of purine analogs: A review. J Clin Oncol 1994;12:2216- 2228.

10. Gardner RA, Finney O, Annesley C, et al. Intent-to-treat leukemia remission by CD19 CAR T cells of defined formulation and dose in children and young adults. Blood 2017; 129:3322-31.

11. Hirschfeld S, Ho P, Smith M, et al: Regulatory approvals of pediatric oncology drugs: Previous experience and new initiatives. J Clin Oncol 2003;21:1066-1073.

12. Hijiya, N., Gaynon, P., Barry, E., Silverman, L., Thomson, B., Chu, R., Carroll, W. A multi-center phase I study of clofarabine, etoposide and cyclophosphamide in combination in pediatric patients with refractory or relapsed acute leukemia. Leukemia 2009;23, 2259-2264.

13. Cordo V, Meijerink J. T-cell Acute Lymphoblastic Leukemia: A Roadmap to Targeted Therapies. Blood Cancer Discov 2001;2: 19-31.

14. Maude SL, Laetsch TW, Buechner J, et al. Tisagenlecleucel in Children and Young Adults with B-Cell Lymphoblastic Leukemia. N Engl J Med 2018;378(5):439-448.

15. Mueller KT, Waldron E, Grupp SA, et al. Clinical pharmacology of tisagenlecleucel in B-cell acute lymphoblastic leukemia. Clin Cancer Res 2018; 24(24):6175-6184.

16. Hunger SP, Mullighan CG. Acute Lymphoblastic Leukemia in Children. N Engl J Med 2015;373 (16): 1541-52. 
17. Milone MC, Fish JD, Carpenito C, et al. Chimeric receptors containing CD137 signal transduction domains mediate enhanced survival of T cells and increased antileukemic efficacy in vivo. Mol Ther 2009;17(8):1453-1464.

18. Lee DW, Stetler-Stevenson M, Yuan CM, et al. safety and response of incorporating CD19 chimeric antigen receptor T cell therapy in typical salvage regimens for children and young adults with acute lymphoblastic leukemia [abstract]. Blood 2015;126: 684.

19. Novartis. Prescribing information (Kymriah). East Hanover, NJ: Novartis Pharmaceuticals Corp., 2021.

20. IBM Micromedex - RedBook, 2021.

21. National Cancer Institute (NCI) (2018). Childhood Acute Lymphoblastic Leukemia Treatment. National Cancer Institute (NCI). Available at: https://www.cancer.gov/types/leukemia/hp/child-all-treatment-pdq (Accessed March 21, 2021)

22. Wheeler K, Chessells JM, Bailey CC, et al: Treatment related deaths during induction and in first remission in acute lymphoblastic leukaemia: MRC UKALL X. Arch Dis Child 1996;74:101-107.

23. Porter DL, Hwang WT, Frey NV, et al. Chimeric antigen receptor T cells per- sist and induce sustained remissions in relapsed refractory chronic lymphocytic leukemia . Sci Transl Med 2015;7: 303ra139.

24. Von Stackelberg A, Locatelli F, Zugmaier G, et al. Phase I/phase II study of blinatumomab in pediatric patients with relapsed/refractory acute lymphoblastic leukemia. J Clin Oncol 2016; 34:4381-9. 
25. Chan K: Acute lymphoblastic leukemia. Curr Probl Pediatr Adolesc Health Care 2002;32:40-49.

26. Chessells J, Veys P, Kempski H, et al: Long- term follow-up of relapsed childhood acute lymphoblastic leukaemia. Br J Haematol 2003;123:396-405.

27. Mansson E, Flordal E, Liliemark J, et al: Down regulation of deoxycytidine kinase in human leukemic cell lines resistant to cladribine and clofarabine and increased ribonucleotide reductase activity contributes to fludarabine resistance. Biochem Pharmacal 2003;65:237-247.

28. Mueller KT, Maude SL, Porter DL, et al. Cellular kinetics of CTL019 in relapsed/refractory B-cell acute lymphoblastic leukemia and chronic lymphocytic leukemia. Blood 2021;130(21):2317-2325.

29. Saarinen-Pihkala UM, Heilmann C, Winiarski J, et al. Pathways through relapses and deaths of children with acute lymphoblastic leukemia: role of allogeneic stem-cell transplantation in Nordic data. J Clin Oncol 2006;24(36):5750- 5762.

30. Turtle C.J., Hanafi LA, Berger C, et al. CD19 CAR-T cells of defined CD4+:CD8+ composition in adult B cell ALL patients. J Clin Invest 2016; 126:2123-38.

31. Yamauchi T, Nowak B, Keating M, et al: DNA repair initiated in chronic lymphocytic leukemia lymphocytes by 4-hydroperoxycyclophosphamide is inhibited by fludarabine and clofarabine. Clin Cancer Res 2001;7:3580-3589.

32. Safety and Efficacy of KTE-C19 in Adults With Refractory Aggressive Non-Hodgkin Lymphoma (ZUMA-1). Clinicaltrials.gov. Available at: 
https://clinicaltrials.gov/ct2/show/NCT02348216?term=Zuma-1\&draw=2\&rank=1 (Accessed March 1, 2021).

33. Social Security. Actuarial Life Table, 2017. Available at:

https://www.ssa.gov/oact/STATS/table4c6.html (Accessed March 1, 2021).

34. Furzer J, Gupta S, Nathan PC, Schechter T, Pole JD, Krueger J, Pechlivanoglou P. Cost-effectiveness of Tisagenlecleucel vs Standard Care in High-risk Relapsed Pediatric Acute Lymphoblastic Leukemia in Canada. JAMA Oncol 2020;1;6(3):393401. 